\title{
Reference Waste Form, Basalts, and Ground Water Systems for Waste Interaction Studies
}

\author{
R. A. Deju \\ R. K. Ledgerwood \\ P. E. Long
}

September 1978

Prepared for the United States

Department of Energy

Under Contract EY-77-C-06-1030

\section{Rockwell International}

Rockwell Hanford Operations

Energy Systems Group

Richland, WA 99352 


\section{DISCLAIMER}

This report was prepared as an account of work sponsored by an agency of the United States Government. Neither the United States Government nor any agency Thereof, nor any of their employees, makes any warranty, express or implied, or assumes any legal liability or responsibility for the accuracy, completeness, or usefulness of any information, apparatus, product, or process disclosed, or represents that its use would not infringe privately owned rights. Reference herein to any specific commercial product, process, or service by trade name, trademark, manufacturer, or otherwise does not necessarily constitute or imply its endorsement, recommendation, or favoring by the United States Government or any agency thereof. The views and opinions of authors expressed herein do not necessarily state or reflect those of the United States Government or any agency thereof. 


\section{DISCLAIMER}

Portions of this document may be illegible in electronic image products. Images are produced from the best available original document. 


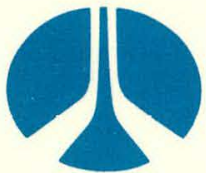

\section{Rockwell International}

\author{
Rockwell Hanford Operations \\ Energy Systems Group \\ Richland, WA 99352
}

\author{
PREPARED FOR THE UNITED STATES DEPARTMENT OF ENERGY \\ UNDER CONTRACT EY-77-C-06-1030
}

\section{PRELIMINARY REPORT}

Tlıis Repur L cunlains infunmalion of a preliminary nature. It is subject to revision or correction and therefore does not represent a final Report. It was prepared primarily for internal use within The Rockwell Hanford Operations. Any expressed views and opinions are those of the Author and not necessarily of the Company.

NOTICE

This Report was prepared as an account of work sponsored by the United States Government. Neither the United States nor the United States Department of Energy, nor any of their Employees, nor any of their Contractors, Subcontractors, or their Employees, makes any warranty, express or implied, or assumes any legal liability or responsibility for the accuracy, complctencss, or uscfulncss of any information, apparatus, product or process disclosed, or represents that its use would not infringe privately owned rights. 


\title{
REFERENCE WASTE FORM, BASALTS, AND GROUND WATER SYSTEMS FOR WASTE INTERACTION STUUIES
}

\author{
R. A. Deju
}

R. K. Ledgerwood

P. E. Long

for

Basalt Waste. Isolation Program

September 1978

UISTRWUTION UY THIS DOCUBENT IS UNLIMTED

Rockwell International

Rockwell Hanford Operations

Energy Systems Group

Richland, Washington 99352 
TABLE OF CONTENTS

$\underline{\text { Page }}$

SUMMARY

WASTE FORM

GLASS

SUPERCALCINE

SPENT UNREPROCESSED FUEL 12

BASALTS

$\begin{array}{ll}\text { POMONA MFIMRFR } & 18\end{array}$

UMTANUM UNIT $\quad 24$

BCR-1 STANDARD $\quad 24$

WATERS $\quad 25$

ENGINEERED BARRIERS 33

SCENARIOS TO BE MODELED $\quad 35$

$\begin{array}{ll}\text { REFERENCES } & 38\end{array}$

$\begin{array}{ll}\text { DISTRIBUTION } & 40\end{array}$

$\begin{aligned} \text { APPENDIX A - PETROGRAPHIC DESCRIPTION OF THE POMONA } & 41 \\ \text { TYPE SECTION } & \end{aligned}$

APPENDIX B - POMONA AND UMTANUM CHEMICAL COMPOSITION 45

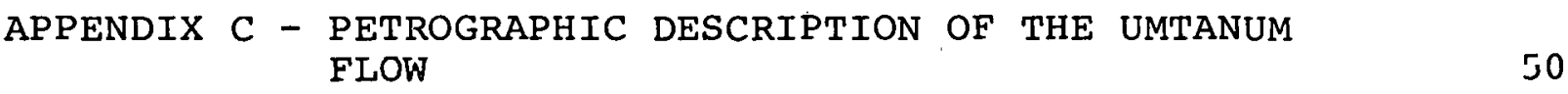

IPPENDIX D - BCR-1 DATA

LIST OF TABLES

TABLE I WASTE FORM PROPERTIES $\quad 6$

TABLE II COMPOSITION OF BATTELLE-NORTHWEST WASTE GLASS 76-68 7

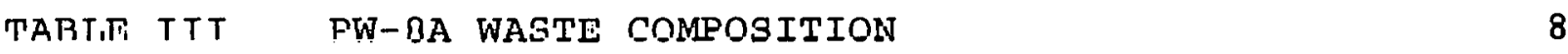

TABLE IV COMPOSITION OF SUPERCALCINE SPC-2

"AABLE V SIMULATED SPENT UNREPROCESSED FUEL FISSION PRODUCTS

TABLE VI SUMMARY OF PHYSICAL AND THERMAL CHARACTERISTICS OF THE POMONA MEMBER 23 
Table of Contents (continued)

\begin{tabular}{|c|c|c|c|}
\hline & & & age \\
\hline TABLE. & VII & MAJOR CONSTITUENTS: ANALYTICAL RESULTS & 27 \\
\hline TABLE & VIII & TRACE CONSTITUENTS: & 28 \\
\hline TABLE & IX & $\begin{array}{l}\text { EXPERIMENTAL CONDITIONS .FOR WASTE/BASALT } \\
\text { COMPATIBILITY EVALUATIONS }\end{array}$ & 37 \\
\hline TABLE & $B-1$ & POMONA AND UMTANUM CHEMICAL COMPOSITION & 46 \\
\hline TABLE & B-2 & POMONA AND UMTAINUM X-RAY FLUORESCENCE & 48 \\
\hline TABLE & $\mathrm{D}-1$ & $\begin{array}{l}\text { BCR-1 - DATA FROM ATLANTIC RICHFIELD HANFORD } \\
\text { COMPANY AND ROCKWELL HANFORD OPERATIONS } \\
\text { ANALYSIS }\end{array}$ & 58 \\
\hline TABLE & $\mathrm{D}-2$ & $\begin{array}{l}1972 \text { VALUES FOR INTERNATIONAL GEOCHEMICAL } \\
\text { STANDARDS FOR BASALT, AFTER FLANAGAN }\end{array}$ & 59 \\
\hline & & LIST OF FIGURES & \\
\hline FIGURE & E 1 & $\begin{array}{l}\text { PORTION OF AN X-RAY DIFFRACTOGRAM OF } \\
\text { CRYSTALLIZED SPC-2 }\end{array}$ & 11 \\
\hline FIGURE & E 2 & $\begin{array}{l}\text { MACROSTRUCTURE OF A GENERALIZED FLOW OR } \\
\text { FLOW UNIT }\end{array}$ & 16 \\
\hline F IGURE & E 3 & PASCO BASIN STRATIGRAPHIC NOMENCLATURE & 17 \\
\hline FIGURE & E 4 & POMONA TYPE LOCALITY LOCATION MAP & 19 \\
\hline FIGURE & E 5 & IDEALIZED SECTION THROUGH THE POMONA MEMBER & 21 \\
\hline FIGURE & E 6 & REPRESENTATIVE TEXTURE OF THE POMONA MEMBER & 22 \\
\hline FIGURE & E 7 & $\begin{array}{l}\text { HANFORD AREA MAP SHOWING LOCATION OF WELLS } \\
\text { SAMPLED }\end{array}$ & 26 \\
\hline FIGURE & E 8 & $\begin{array}{l}\text { MAJOR CONSTITUENTS OF DB-I (DUPLICATE SAMPLES) } \\
\text { WATER FROM THE MABTON MEMBER }\end{array}$ & 29 \\
\hline FIGURE & E 9 & $\begin{array}{l}\text { MAJOR CONSTITUENTS IN DB-2 (DUPLICATE SAMPLES) } \\
\text { WATER FROM THE MABTON MEMBER }\end{array}$ & 30 \\
\hline FIGURE & E 10 & $\begin{array}{l}\text { MAJOR CONSTITUENTS IN DB-7 (DUPLICATE SAMPLES) } \\
\text { WATER FROM THE MABTON MEMBER }\end{array}$ & 31 \\
\hline FIGURE & E 11 & $\begin{array}{l}\text { MAJOR CONSTITUENTS IN RSH-1 (DUPLICATE SAMPLES) } \\
\text { WATER FROM THE GRANDE RONDE FORMATION }\end{array}$ & 32 \\
\hline FIGURE & $\mathrm{E} B-$ & $\begin{array}{l}\text { HANFORD AREA MAP SHOWING LOCATION OF WELLS } \\
\text { SAMPLED }\end{array}$ & 9 \\
\hline
\end{tabular}




\section{SUMMARY}

This report summarizes the type of waste form, basalt, and ground water compositions to be used in theoretical and experimental models of the geochemical environment to be simulated in studying a typical basalt repository.

Waste forms to be used in the experiments include, and are limited to, glass, supercalcine, and spent unreprocessed fuel. Reference basalts selected for study include the Pomona member and the Umtanum Unit, Shwanna Member, of the Columbia River Basalt Group. In addition, a sample of the Basalt International Geochemical standard (BCR-1) will be used for cross-comparison purposes. The representative water to be used is of a sodium bicarbonate composition as determined from results of analyses of deep ground waters underlying the Hanford site.

At present, the experiments do not include an analysis of overpack material and/or container materials, inasmuch as the nature of these materials will be determined as a result of the experiments on the interactions in the absence of these materials. 
WASTE FORM

The present emphasis in the United States' Terminal Storage Program is not to reprocess spent fuel elements. Due to this directive, we are considering spent unreprocessed fuel to be our prime radioactive waste form to be stored in a potential basalt cavern.

If the decision were made to reprocess spent fuel with its resultant high-level waste stream, a vitrification process yielding a glass product would probably be the leading contender for the solid waste form, since it has, to date, received the majority of research and development funding.

In order to ensure the comprehensiveness of our current waste/basalt interaction studies, we have chosen to include the following waste forms in our experiments: spent unreprocessed fuel; glass; and supercalcine.

As a first step in analyzing the physical and chemical effects of storing nuclear waste in an underground basalt repository, one must first deal with the waste forms themselves. Needless to say, each waste form has its own set of unique characteristics (chemical and radiological composition, mineralogy, structure, thermal energy, physical properties, etc.) which will have a direct bearing upon the storage concept. Table I summarizes many of these properties for the above waste forms. (1)

\section{GLASS}

The composition of glass chosen for study will be the same specimen being used in the source term characterization task of the Office of Nuclear Waste Isolation/Battelle-Northwest/Waste Isolation Safety Assessment Program. Its code is 76-68 and its composition is given in Table II. The waste composition (PW-8a) used to prepare glass $76-68$ is given in Table III. 
TABLE I

WASTE FORM PROPERTIES

\begin{tabular}{|c|c|c|c|c|c|c|}
\hline PROPERTY & UNITS & $\begin{array}{l}\text { SUPER } \\
\text { CAICINE } \\
\text { POHDER }\end{array}$ & $\begin{array}{l}\text { SUPER } \\
\text { CALCINE } \\
\text { CERAMIC }\end{array}$ & $\begin{array}{c}\text { PHOSPHATE } \\
\text { GLHSS }\end{array}$ & $\begin{array}{c}\text { BORO- } \\
\text { SILICATE } \\
\text { GLASS }\end{array}$ & $\begin{array}{l}\text { SPENT FUEL } \\
\text { PELLETS }\end{array}$ \\
\hline $\begin{array}{l}\text { SOLUTION } \\
\text { RATE }\end{array}$ & $\frac{m g}{m^{2} \sec }$ & $\begin{array}{l}10^{-6} \\
\text { to } \\
10^{-4}\end{array}$ & $\begin{array}{l}10^{-7} \\
50^{-5} \\
10^{-5}\end{array}$ & $\begin{array}{l}10^{-5} \\
\text { to } \\
0.7\end{array}$ & $\begin{array}{l}10^{-5} \\
\text { to } \\
0.01\end{array}$ & $\begin{array}{l}10^{-2} \\
\text { to } \\
10^{-5}\end{array}$ \\
\hline $\begin{array}{l}\text { CORROSION } \\
\text { TO CLAD } \\
\text { MATERIAL }\end{array}$ & $\mathrm{nm} / \mathrm{sec}$ & $\begin{array}{l}0 \\
\text { to } \\
10\end{array}$ & $\begin{array}{l}0 \\
\text { to } \\
10\end{array}$ & $\begin{array}{l}0 \\
\text { to } \\
10\end{array}$ & $\begin{array}{l}0 \\
\text { to } \\
10\end{array}$ & * \\
\hline $\begin{array}{l}\text { RESIDUAL } \\
\text { NITRITE } \\
\text { AND/OR } \\
\text { VATER }\end{array}$ & 8 & $\begin{array}{l}0.005 \\
\text { to } \\
0.05\end{array}$ & $\begin{array}{l}0.005 \\
\text { to } \\
0.01\end{array}$ & $\begin{array}{l}0.005 \\
00 \\
0.05\end{array}$ & $\begin{array}{l}0.005 \\
\text { to } \\
0.05\end{array}$ & $<.005$ \\
\hline $\begin{array}{l}\text { MAXIMUM } \\
\text { PROCESSING } \\
\text { TEMPERATURE }\end{array}$ & ${ }^{\circ} \mathrm{X}$ & $\begin{array}{l}1.370 \\
t 0 \\
1.570\end{array}$ & $\begin{array}{l}1.370 \\
\text { to } \\
1.570\end{array}$ & 1.170 & $\begin{array}{l}1,270 \\
\text { to } \\
1,670\end{array}$ & NA \\
\hline $\begin{array}{l}\text { RUTHENIUM } \\
\text { VOLATILIZED } \\
\text { AT PROCESSING }\end{array}$ & 8 & $\leq 7.0$ & $\leq 5.0$ & $\begin{array}{l}3 \\
\text { to } \\
15\end{array}$ & $\leq 2.0$ & NA \\
\hline VOLATILITY & NA & $\begin{array}{l}1.570^{\circ} \mathrm{K} \\
\text { some } \\
\text { Ru } \mathrm{S} \mathrm{Cs}\end{array}$ & $\begin{array}{l}1.670^{\circ} \mathrm{K} \\
\text { much } \\
\text { Ru \& Cs }\end{array}$ & $\begin{array}{l}=1,500^{\circ} \mathrm{K} \\
\text { all } \\
\text { Ru } \& \mathrm{Cs}\end{array}$ & $\begin{array}{l}1.500^{\circ} \mathrm{K} \\
\mathrm{all} \\
\mathrm{Ru} \& \mathrm{Cs}\end{array}$ & NA \\
\hline $\begin{array}{l}\text { SHECIFIC } \\
\text { VOLUME }\end{array}$ & $\frac{m^{3}}{M g U}$ & 0.070 & 0.070 & $\begin{array}{l}0.036 \\
\text { to } \\
0.078\end{array}$ & $\begin{array}{l}0.04 \\
\text { to } \\
0.1\end{array}$ & $\longrightarrow$ \\
\hline $\begin{array}{l}\text { WEIGHT FERCENT } \\
\text { WASTE PRODUCT } \\
\text { OXIDES }\end{array}$ & $\begin{array}{l}\text { MEXIMUM } \\
\text { TYPICAL }\end{array}$ & $\begin{array}{l}\leq 75 \xi \\
45 q\end{array}$ & $\begin{array}{l}\leq 758 \\
458\end{array}$ & $\begin{array}{l}\leq 25 \varepsilon \\
20 \varepsilon\end{array}$ & $\begin{array}{l}\leq 50 \varepsilon \\
20-35 q\end{array}$ & $\begin{array}{l}58 \\
48\end{array}$ \\
\hline $\begin{array}{l}\text { SPECIFIC } \\
\text { AREA. }\end{array}$ & $\frac{m^{2}}{k g}$ & $\begin{array}{l}10,000 \\
\text { to } \\
20,000\end{array}$ & $\begin{array}{l}0.005 \\
\text { to } \\
0.05\end{array}$ & $\begin{array}{l}0.005 \\
\text { to } \\
0.05\end{array}$ & $\begin{array}{l}0.005 \\
\text { to } \\
0.05\end{array}$ & - \\
\hline FORM & NA & Powder & Monolitic & $\begin{array}{l}\text { ractured } \\
\text { Monclith }\end{array}$ & $\begin{array}{l}\text { Fractured } \\
\text { Monolith }\end{array}$ & $\begin{array}{l}\text { Fractured } \\
\text { pellets }\end{array}$ \\
\hline $\begin{array}{l}\text { STRUCTURAL } \\
\text { OLALITY }\end{array}$ & NA & $\begin{array}{l}\text { Soft } \delta \\
\text { Crumbiy }\end{array}$ & $\begin{array}{l}\text { very Hard } \\
\text { o Brittle }\end{array}$ & $\begin{array}{l}\text { Very Harc } \\
\text { S } B=i t=i e\end{array}$ & $\begin{array}{l}\text { Very Hard } \\
\text { s Brittle }\end{array}$ & $\begin{array}{l}\text { Very Hard } \\
\text { \& Brittle }\end{array}$ \\
\hline POROSIT: & 8 & $\begin{array}{l}40 \\
50 \\
50\end{array}$ & $\begin{array}{l}2 \\
t: \pi \\
20\end{array}$ & 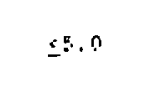 & $=1.0$ & $\begin{array}{l}2 \\
10 \\
10\end{array}$ \\
\hline DENSITY & $\frac{k c}{m^{3}}$ & 4.000 & $\begin{array}{l}3,500 \\
50 \\
4,000\end{array}$ & $\begin{array}{l}2.700 \\
t 0 \\
3.000\end{array}$ & $\begin{array}{l}3,000 \\
\text { to } \\
3,600\end{array}$ & $\begin{array}{l}10,000 \\
\text { to } \\
10,500 \ldots\end{array}$ \\
\hline $\begin{array}{l}\text { COEFFICIE:T } \\
\text { OT LINEAF. } \\
\text { EXPANSIOK }\end{array}$ & $\times 10^{-6}, 0 \mathrm{x}$ & $\approx 8.3$ & $\begin{array}{l}8 \\
\text { to } \\
10\end{array}$ & $\begin{array}{l}8 \\
\text { to } \\
10\end{array}$ & $\begin{array}{l}8 \\
\text { to } \\
10\end{array}$ & $210 * \star$ \\
\hline $\begin{array}{l}\text { THEPNA.L } \\
\text { CONDUCTIVITY }\end{array}$ & $\frac{w}{m^{6} k}$ & $0 . \epsilon$ & $\begin{array}{l}0.8 \\
\text { to } \\
2\end{array}$ & $\begin{array}{r}0 . \varepsilon \\
=0 \\
i .3\end{array}$ & $\begin{array}{r}0.9 \\
\text { to } \\
1.3\end{array}$ & $\begin{array}{l}2 \star \star \\
\text { to } \\
6\end{array}$ \\
\hline $\begin{array}{l}\text { CEAT } \\
\text { CAPACITY }\end{array}$ & $\frac{\pi}{\sin x}$ & 514 & $\begin{array}{c}1.100 \\
\text { to } \\
1.200\end{array}$ & $\begin{array}{l}1.100 \\
100 \\
1.200\end{array}$ & $\cdot \quad 750$ & $\begin{array}{l}238 * * \\
6 U \\
330\end{array}$ \\
\hline $\begin{array}{l}\text { OIOUIDUS } \\
\text { TFPSERTUPE }\end{array}$ & ${ }^{\circ} \mathrm{K}$ & $\begin{array}{c}1.670 \\
\text { to } \\
1.870\end{array}$ & $\begin{array}{l}1.670 \\
20 \\
1.870\end{array}$ & $\begin{array}{l}520 \\
r 0 \\
\vdots .020\end{array}$ & $\begin{array}{l}800 \\
\text { to } \\
1,500\end{array}$ & $-3,138 * *$ \\
\hline $\begin{array}{l}\text { TPENSITIOR: } \\
\text { TENPERUTURE }\end{array}$ & $\because:$ & N: & Nr: & 770 & $\begin{array}{l}870 \\
\text { to } \\
970\end{array}$ & NA \\
\hline
\end{tabular}

Y: T2 s:MoLs

$=$ ::o= $\because \cdots: j a b j \in$

$\because$ * liz: boplicabie

$+2$

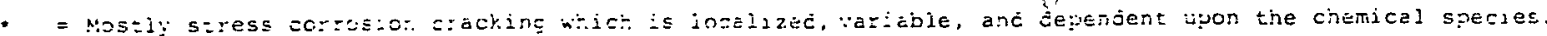

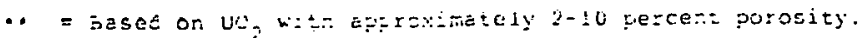

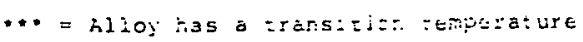




\section{TABLE II}

COMPOSITON OF BATTELLE-NORTHWEST

WASTE GLASS 76-68*

\begin{tabular}{|c|c|c|c|c|c|}
\hline Oxide & Wt. 8 & Oxide & Wt. \% & Oxide & Wt. $q$ \\
\hline $\mathrm{SiO}_{2}$ & 39.8 & $\mathrm{MOO}_{3}$ & 2.3 & $\mathrm{P}_{2} \mathrm{O}_{5}$ & 0.5 \\
\hline $\mathrm{Na}_{2} \mathrm{O}$ & 12.5 & $\mathrm{CaO}$ & 2.0 & $\mathrm{Cr}_{2} \mathrm{O}_{3}$ & 0.4 \\
\hline $\mathrm{Fe}_{2} \mathrm{O}_{3}$ & 9.8 & $\mathrm{ZrO}_{2}$ & 1.8 & Sro & 0.4 \\
\hline $\mathrm{B}_{2} \mathrm{O}_{3}$ & 9.5 & $\mathrm{CeO}_{2}$ & 1.2 & $\mathrm{TeO}_{2}$ & 0.3 \\
\hline $\mathrm{Zno}$ & 5.0 & $\mathrm{RuO}_{2}$ & 1.1 & NiO & 0.2 \\
\hline $\mathrm{U}_{3} \mathrm{O}_{8}$ & 4.6 & $\mathrm{Cs}_{2} \mathrm{O}$ & 1.0 & $\mathrm{Rh}_{2} \mathrm{O}_{3}$ & 0.2 \\
\hline $\mathrm{RE}_{2} \mathrm{O}_{3} * \star$ & 3.4 & $\mathrm{BaO}$ & 0.6 & $\mathrm{Rb}_{2} \mathrm{O}$ & 0.1 \\
\hline $\mathrm{TiO}_{2}$ & 3.0 & Pdo & 0.5 & Others & 0.1 \\
\hline
\end{tabular}

*Modified from a table provided by D. J. Bradley, BattelleNorthwest.

$\star \star \mathrm{RE}=\mathrm{La}, \operatorname{Pr}, \mathrm{Nd}, \mathrm{Sm}, \mathrm{Eu}, \mathrm{Gd}, \mathrm{Y}$. 
TABLE III

PW-8A WASTE COMPOSITION*

(Kgs Oxide/MTU)

Inerts

Fission

products

Actinides

* See reference 7 .

$\begin{array}{lr}\mathrm{Na}_{2} \mathrm{O} & 14.057 \\ \mathrm{Fe}_{2} \mathrm{O}_{3} & 27.225 \\ \mathrm{Cr}_{2} \mathrm{O}_{3} & 1.151 \\ \mathrm{NiO} & 0.566 \\ \mathrm{P}_{2} \mathrm{O}_{5} & 1.342\end{array}$

$\mathrm{Rb}_{2} \mathrm{O}$

0.354

Sro

1.059

$\mathrm{Y}_{2} \mathrm{O}_{3}$

0.598

$\mathrm{ZrO}_{2}$

4.944

$\mathrm{MOO}_{3}$

5.176

$\mathrm{TC}_{2} \mathrm{O}_{7}$

1.291

$\mathrm{RuO}_{2}$

2.972

$\mathrm{Rh}_{2} \mathrm{O}_{3}$

0.480

Pdo

1.483

$\mathrm{Ag}_{2} \mathrm{O}$

0.088

cdo

0.097

$\mathrm{TeO}_{2}$

0.725

$\mathrm{Ca}_{2} \mathrm{O}$

2.080

BaO

1.567

$\mathrm{La}_{2} \mathrm{O}_{3}$

1.480

$\mathrm{CeO}_{2}$

3.323

$\mathrm{Pr}_{6} \mathrm{O}_{11}$

1.482

$\mathrm{Nd}_{2} \mathrm{O}_{3}$

4.522

$\mathrm{Pm}_{2} \mathrm{O}_{3}$

0.123

$\mathrm{Sm}_{2} \mathrm{O}_{3}$

0.924

$\mathrm{Eu}_{2} \mathrm{O}_{3}$

0.200

$\mathrm{Gd}_{2} \mathrm{O}_{3}$

0.137

$\mathrm{U}_{3} \mathrm{O}_{8}$

11.689

$\mathrm{NpO}_{2}$

0.865

$\mathrm{PuO}_{2}$

0.174

$\mathrm{Am}_{2} \mathrm{O}_{3}$

0.181

$\mathrm{Cm}_{2} \mathrm{O}_{3}$

0.040 
A great deal of experimentation has taken place using this reference glass and other glasses. Ross(2) has discussed the development of glass formulations containing high-level nuclear wastes. Others at Battelle have detailed numerous studies to characterize.high-level waste glasses and examine their volatility and devitrification behavior.(3-6) A recent Battelle report (7) discusses some miscellaneous experiments with 76-68 and other waste glass formulations.: An important conclusion from the above experiments is that the 76-68 (low Zno) waste glass form. shows much improved resistance to acid attack with little change over the pH 4-12 range. In glass 76-68 where devitrification rates are very slow, elemental differences between as-formed and thermally treated samples have not been significant. Average leach rates based on cesium from the 76-68 waste glass in an International Atomic Energy Agency type long-term test are about $3.3 \times 10^{-8} \mathrm{~g} / \mathrm{cm}^{2} /$ day.

\section{SUPERCALCINE}

The specific formulation of supercalcine to be used for study is SPC-2 prepared as described by MCCarthy ${ }^{(8)}$ on the spray calciner at Battelle and crystallized by firing at $1,125^{\circ} \mathrm{C}$ for two to four hours.

The complete composition of SPC-2 oxides is given in Table IV and a portion of an X-ray diffractogram of crystallized SPC is shown in Figure 1. The srystal.line phases and their shorthand notation in SPC-2 are:(1)

$\begin{array}{ll}\mathrm{Ca}_{2} \mathrm{RE}_{8}\left(\mathrm{SiO}_{4} \mathrm{l}_{6} \mathrm{O}_{2}\right. & {[\mathrm{Ass}]} \\ \mathrm{REPO}_{4} & {[\mathrm{Mss}]} \\ \text { Tetragonal- } \mathrm{ZrO}_{2} & {[\mathrm{Tss}]} \\ (\mathrm{Ca}, \mathrm{Sr}, \mathrm{Ba}) \mathrm{MOO}_{4} & {[\mathrm{Sss}]} \\ (\mathrm{Cs}, \mathrm{Rb}, \mathrm{Na}) \mathrm{AlSi}_{2} \mathrm{O}_{6} & {[\mathrm{P}]} \\ \left(\mathrm{Ce}, \mathrm{Zr}, \mathrm{CO}_{2}\right. & {[\mathrm{Fss}]} \\ (\mathrm{Fe}, \mathrm{Cr})_{2} \mathrm{O}_{3} & {\left[\left(\mathrm{Fe} \mathrm{O}_{3}\right) \mathrm{ss}\right]} \\ (\mathrm{Ni}, \mathrm{Fe})(\mathrm{Fe}, \mathrm{Cr})_{2} \mathrm{O}_{4} & {[\mathrm{SPss}]}\end{array}$


TABLE IV

COMPOSITION OF SUPERCALCINE SPC-2

\begin{tabular}{|c|c|c|c|c|c|c|c|c|c|}
\hline Ion & & & Molarity & & Oxide & $\begin{array}{l}\text { Grams } \\
\text { of } c\end{array}$ & $\begin{array}{l}\text { Oxide Per Liter } \\
\text { Calcined SPC- } 2\end{array}$ & Weig. & arcent \\
\hline & & & & & & & & & \\
\hline $\mathrm{Ce}$ & & $\because$ & 0.261 & & $\mathrm{CeO}_{2}$ & & 27.7 & 16.3 & $(12.7)^{1}$ \\
\hline $2 r$ & & & 0.106. & & $\mathrm{zrO}_{2}$ & & 13.0 & 7.6 & $(5.9)$ \\
\hline$R E^{2}$ & & & $0.102^{2}$ & & $R E_{2} O_{3}$ & & 17.0 & 10.0 & $(7.8)$ \\
\hline $\mathrm{Fe}$ & & & 0.100 & & $\mathrm{Fe}_{2} \mathrm{O}_{3}$ & & 8.0 & 4.7 & $(3.7)$ \\
\hline$\left[\mathrm{PO}_{4}\right]$ & & & 0.100 & & $\mathrm{P}_{2} \mathrm{O}_{5}$ & & 7.1 & 4.2 & $(3.2)$ \\
\hline Mo & & & 0.095 & & $\mathrm{MOO}_{3}$ & & 13.7 & 8.0 & $(6.3)$ \\
\hline La. & & & 0.094 & & $\mathrm{La}_{2} \mathrm{O}_{3}$ & & 25.3 & 9.0 & $(7.0)$ \\
\hline $\mathrm{CB}$ & . & & 0.054 & & $\mathrm{Cr}_{2} \mathrm{O}$ & . & 7.6 & 4.5 & $(3.5)$ \\
\hline Sr & . & & 0.027 & & sro & . & 2.8 & 1.6 & $(1.3)$ \\
\hline Ba & & . & 0.027 & · & BaO & & 4.1 & 2.4 & $(1.9)$ \\
\hline Cr & & & 0.012 & & $\mathrm{Cr}_{2} \mathrm{O}_{3}$ & . & 0.9 & 0.5 & $(0.4)$ \\
\hline$R b$ & $\cdot$ & & 0.010 & & $\mathrm{Rb}_{2} \mathrm{O}$ & • & 0.9 & 0.5 & $(0.4)$ \\
\hline Ma & & & 0.010 & 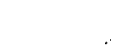 & $\mathrm{Na}_{2} \mathrm{O}$ & . & 0.3 & 0.2 & $(0.1)$ \\
\hline $\mathrm{Ru}^{3}$ & & & 0.006 & - & $\mathrm{RuO}_{2}$ & & 0.8 & 0.5 & $(0.4)$ \\
\hline$M i$ & $\cdot$ & . & 0.005 & $\therefore$ & Nio & & 0.4 & 0.2 & $(0.2)$ \\
\hline Cd & & & 0.002 & . & cáo & & 0.3 & 0.2 & $(0.1)$ \\
\hline
\end{tabular}

SUPERCALCINE ADDITIVES:

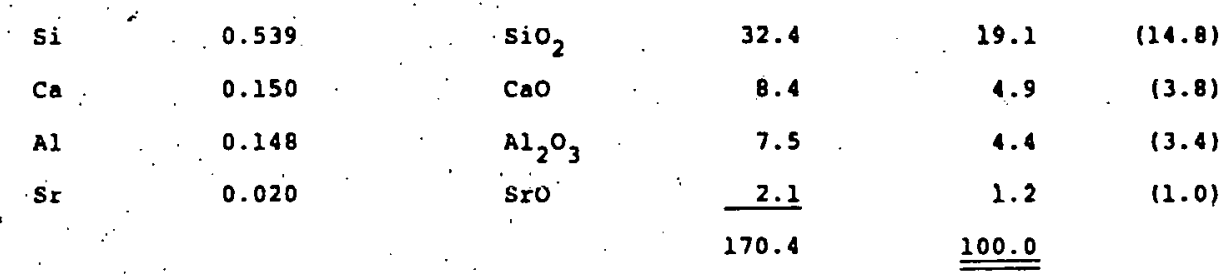

$(70.5$ percent waste loading)

OTHER WASTE CONSTITUENTS:

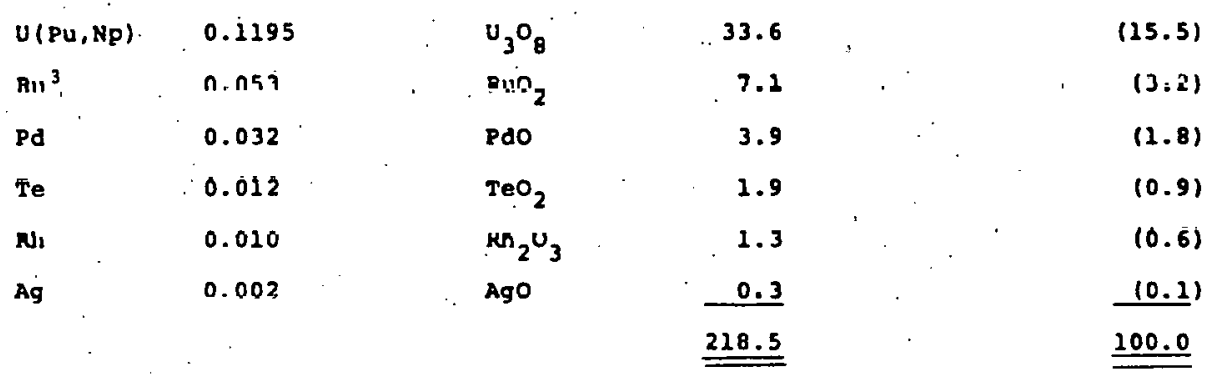

(76.9 percent waste loading)

${ }^{1}$ Value in parentheses is the weight percent of the oxide after addition of the appropriate amounts of $\mathrm{U}, \mathrm{Ru}, \mathrm{Pd}, \mathrm{Te}, \mathrm{Rh}, \mathrm{Ag}$.

${ }^{2} \mathrm{RE}=0.061 \mathrm{Nd}+0.019 \mathrm{Pr}+0.011 \mathrm{Sm}+0.007 \mathrm{Gd}+0.003 \mathrm{Y}$ (Note: $0.002 \mathrm{RE}$ is a stand-in for $A m+C m)$.

${ }^{3} \mathrm{Ru}$ concentration in the spray supercalcine SPC was 10 percent of the actual PW-7 value of $0.059 \mathrm{M}$. The addition of the remaining $0.053 \mathrm{M}$ was made after calculation.

"These constituents were not included in the large batch of SPC-2 because of their expense or radioactivity. None require fixation additives. The only PW-7 cono+ituent not included above ia TC. 


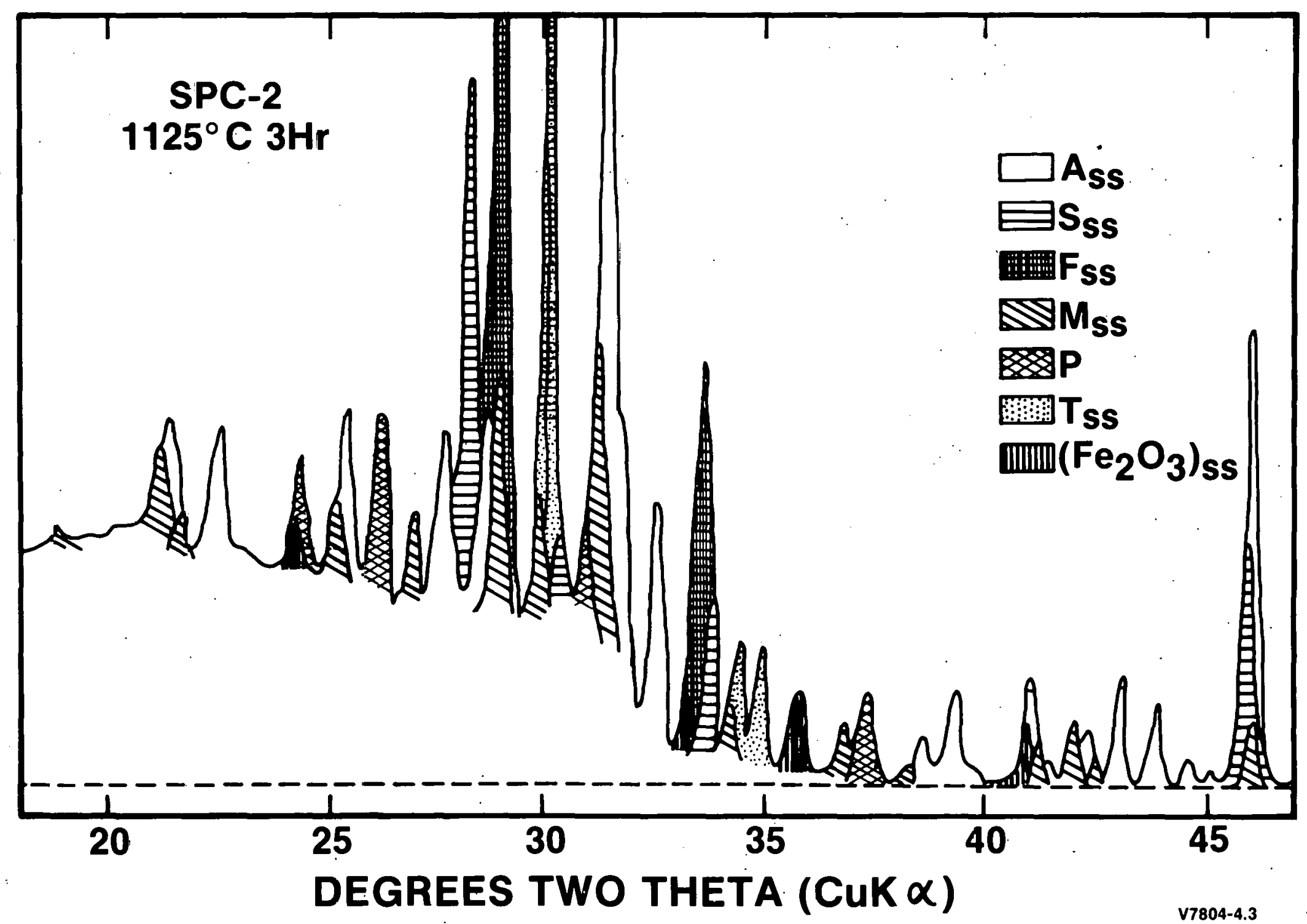

PORTION CF AN X-RAY DIFFRACTOGRAM OF CRYSTALLIZED SPC-2 


\section{SPENT UNREPROCESSED FUEL}

Spent unreprocessed fuel (SURF) from light water reactors (LWR) consist of pellets of $\mathrm{UO}_{2}$ plus a small amount of fission products clad in high zirconium alloy (zircaloy) tubes. Cohen $\left({ }^{9}\right)$ " has shown that nuclear fuel from a LWR having a burnup of 33,000 MWd/MTU will consist of approximately 3.5 wt.o fission products and 96.5 wt. $8 \mathrm{UO}_{2}\left(+\mathrm{NpO}_{2}+\mathrm{PuO}_{2}\right)$. In the SURF formulation for this study, $\mathrm{UO}_{2}$ should be used as a standin for $\mathrm{NpO}_{2}+\mathrm{PuO}_{2}$.

The number of elements in fission products includes more than $1 / 3$ of the periodic table. Table $V$ lists elements or stand-ins that are present in the fission products at $>0.2$ wt. $\%$. The actinides $\mathrm{Am}$ and $\mathrm{Cm}$ are produced by neutron capture rather then fission, but they are included with Gd because of their crystal chemical similarity to this element. Radioactive $\mathrm{TC}$, gaseous $\mathrm{Kr}$, and $\mathrm{Xe}$ and $\mathrm{I}$ are not included in this fission product mix.

The atomic concentrations of the elements in Table $\mathrm{V}$ come from the ORIGIN code or an LWR fuel having a burnup of 33,000 MWd/MTU. The third column in the table gives the recipe for obtaining these concentrations of a mixture of nitrates and oxides. The nitrates, nitrate solutions, and oxides should be mixed vigorously with a large excess of water to give a homogeneous solution-suspension and should then be dried as rapidy as possible on a stirrer-hot plate. The residue should further be dried at $90^{\circ} \mathrm{C}$ and then slowly heated to $400^{\circ} \mathrm{C}$ in air to decompose most of the nitrate. These conditions are selected to minimize alkali and ruthenium volatilization. The final product should be ground thoroughly. 
SIMULATED SPENT UNREPROCESSED FUEL FISSION PRODUCTSa

(burn-up of $33,000 \mathrm{MWd} / \mathrm{MTU}$ )

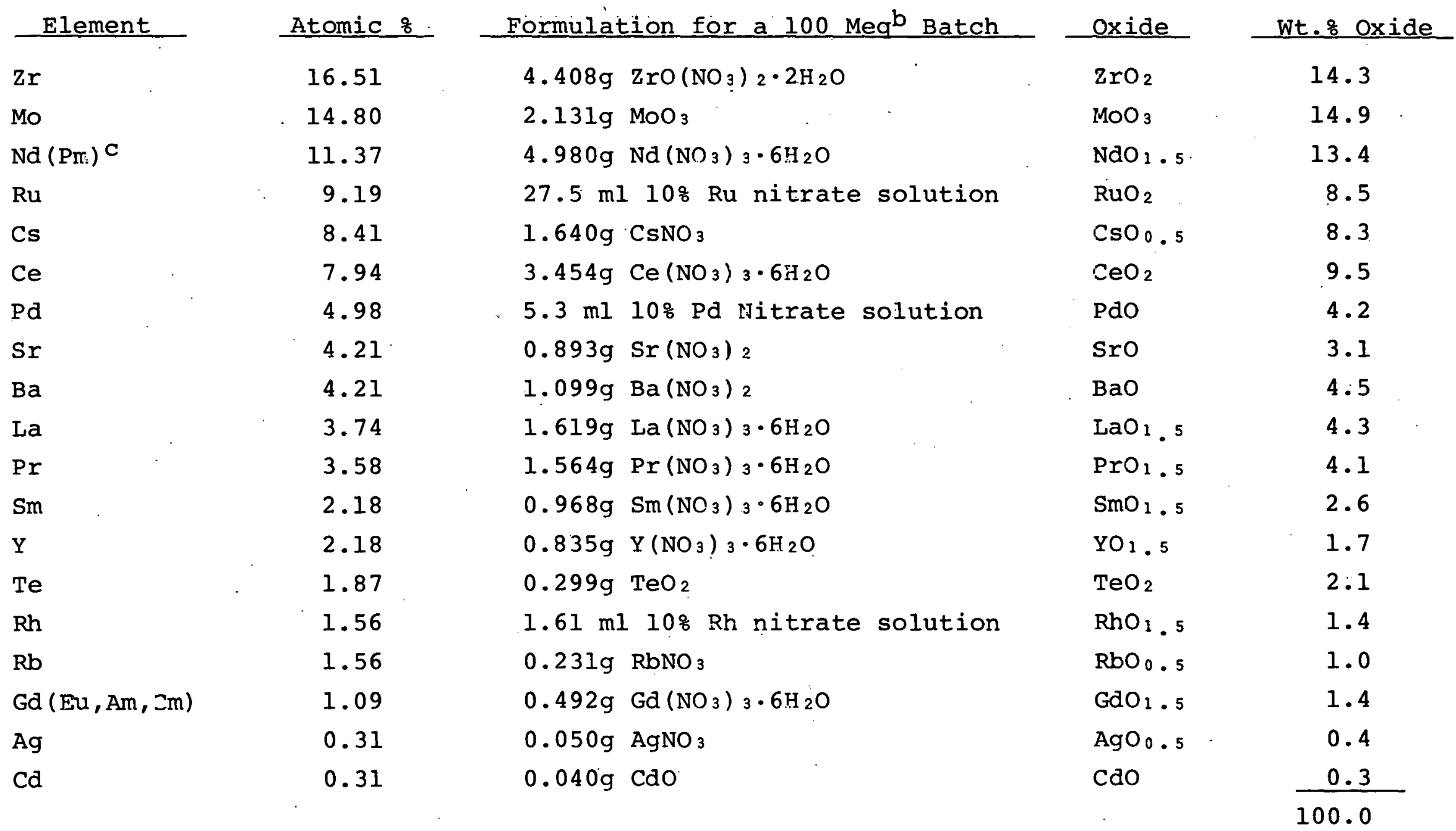

\footnotetext{
$a_{T C,}$, Er, and $X e$ are not included.

$\mathrm{b}_{\text {Milliequivalent. }}$

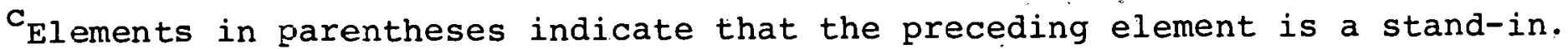


The conditions in actual spent fuel are highly reducing as controlled by the initial stoichiometry of the uranium dioxide fuel. Thus, some of the fission products in a SURF formulation will be present as metals rather than as dioxides produced in this procedure until this point. Therefore, an additional step should be included in the formulation that would provide reducing conditions where the appropriate oxides are converted to metals. To accomplish this, the oxidized product should be placed on a platinum boat in a Vycor tube and fired at $600^{\circ} \mathrm{C}$ in flowing hydrogen for four hours. This treatment should be sufficient to reduce the ruthenium, palladium, tellurium, rhodium, and silver oxides to metals and $\mathrm{CeO}_{2}$ to $\mathrm{Ce}_{2} \mathrm{O}_{3}$.

The reduced fission product mix should be combined with uranium dioxide to give the 96.5 percent $\mathrm{UO}_{2}, 3.5$ percent fission product composition. Because the actual phase in which each fission product species is combined can have a major influence on its dissolution behavior or reactivity, it is then necessary to treat the mixture at a high enough temperature to promote phase formation. This firing must be performed in a closed system to prevent this specimen from oxidizing.

The major phase in SURF is a crystalline fluorite structure $\left(\mathrm{UO}_{2}\right)$ with fluorite-related structure fission product oxides $\left(\mathrm{RE}_{2} \mathrm{O}_{2}, \mathrm{CeO}_{2}\right.$, and some $\left.\mathrm{ZrO}_{2}\right)$ in solid solution. After a survey of papers on irradiated fuel behavior, it became clear that very little else is actually known about spent unreprocessed fuel crystalline phase behavior. It is widely believed that $\mathrm{SrO}$ and $\mathrm{BaO}$ react with $\mathrm{ZrO}_{2}$ to form the perovskite structure $\left[(\mathrm{Ba}, \mathrm{Sr}) \mathrm{ZrO}_{3}\right]$. There also appear to be distinct Cs-Te-rich zones. Cesium is thought to be present as a cesium molybdate and/or a cesium uranate, both of which are quite soluble in watex. The bulk of the $\mathrm{UO}_{2}-\mathrm{rich}$ spent unreprocessed fuel waste form would remain relatively unreactive under hydrothermal repository ambients, as long as the Eh-pH conditions keep the uranium in the tetravalent state. 


\section{BASALTS}

The Columbia River Basalt is classed as tholeiitic basalt on the basis of its chemistry and mineralogy. Not all flows within the Pasco Basin fit this classification because of their higher alkali content. The common minerals present in the basalt are plagioclase, clinopyroxene, olivine, opaque minerals (such as magnetite and ilmenite), apatite, and mineraloids (chlorophaeite). Tachylyte, a basalt glass crowded with crystallites, is abundant in most flows. The plagioclase is usually labradorite where it occurs as large phenocrysts, but may range from labradorite to andesine in the groundmass. olivine is usually altered to clay minerals or Mg-chlorite. The pyroxene present is augite and/or pigeonite. The texture is aphanitic with rare large phenocrysts present in some flows. Although some flows in the Pasco Basin are quite glassy, most exhibit intersertal to intergranular textures. Some show a patchy diktytaxitic ophimottling. The color of the rock is generally gray to black on a fresh surface. Some flows have reddish-orange to reddish-brown weathered surfaces that result from the oxidation of iron in iron-rich clay and mineraloid present in the flow.

The macrostructure of a generalized flow or flow unit is depicted in Figure 2. $(10)$, The stratigraphy of the various flow units in the Pasco Basin is shown in Figure 3.

As part of our waste-basalt interaction studies, three reference samples will be used. Samples of Pomona (high Mgo), and Umtanum types ( $10 \mathrm{~W} \mathrm{MgO}$ ) and a basalt standard BCR-1 will be used. Data on these samples are given in subsequent sections of this report. 


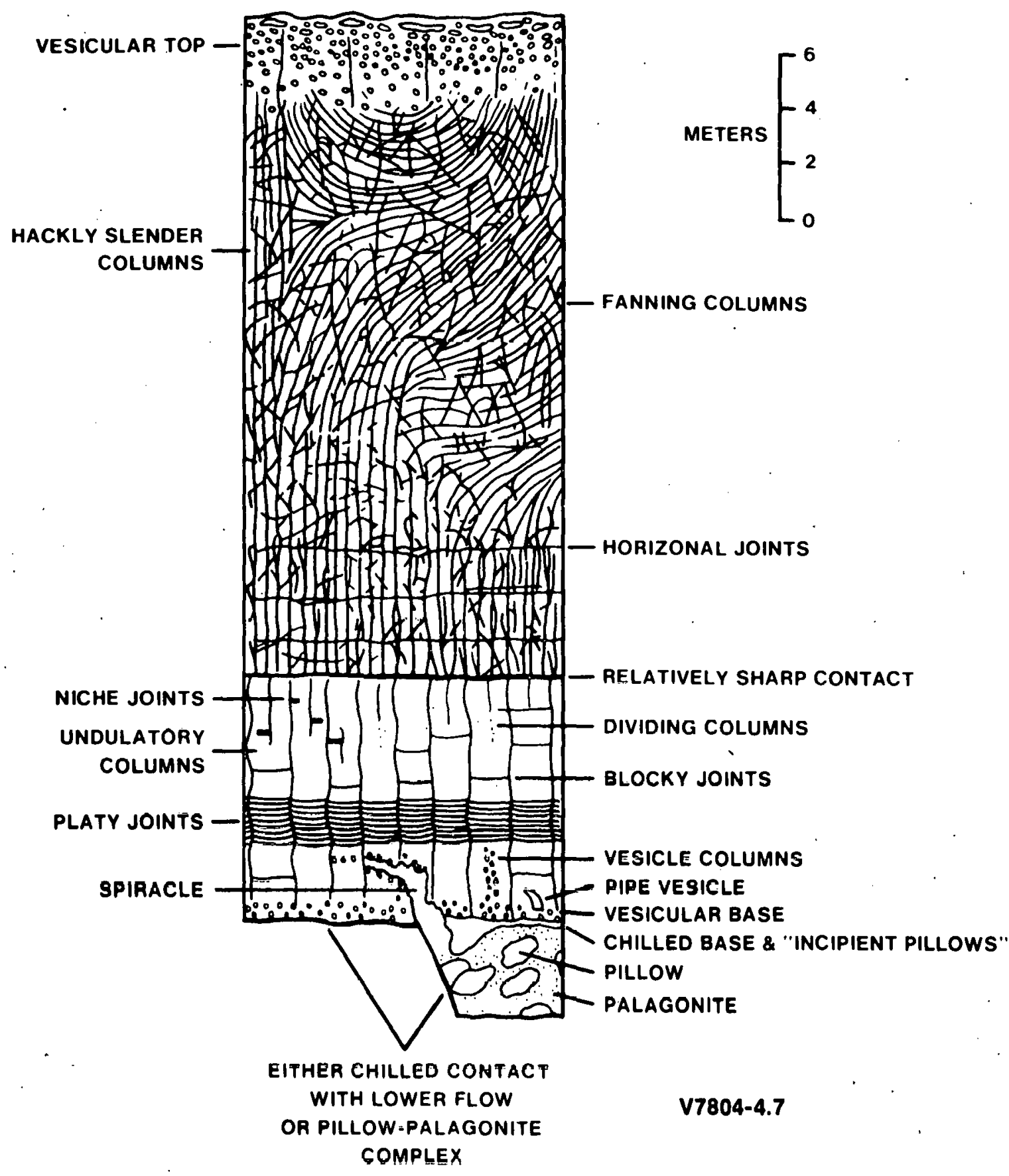

FIGURE 2

MACROSTRUCTURE OF A GENERALIZED FLOW OR FLOW UNIT 


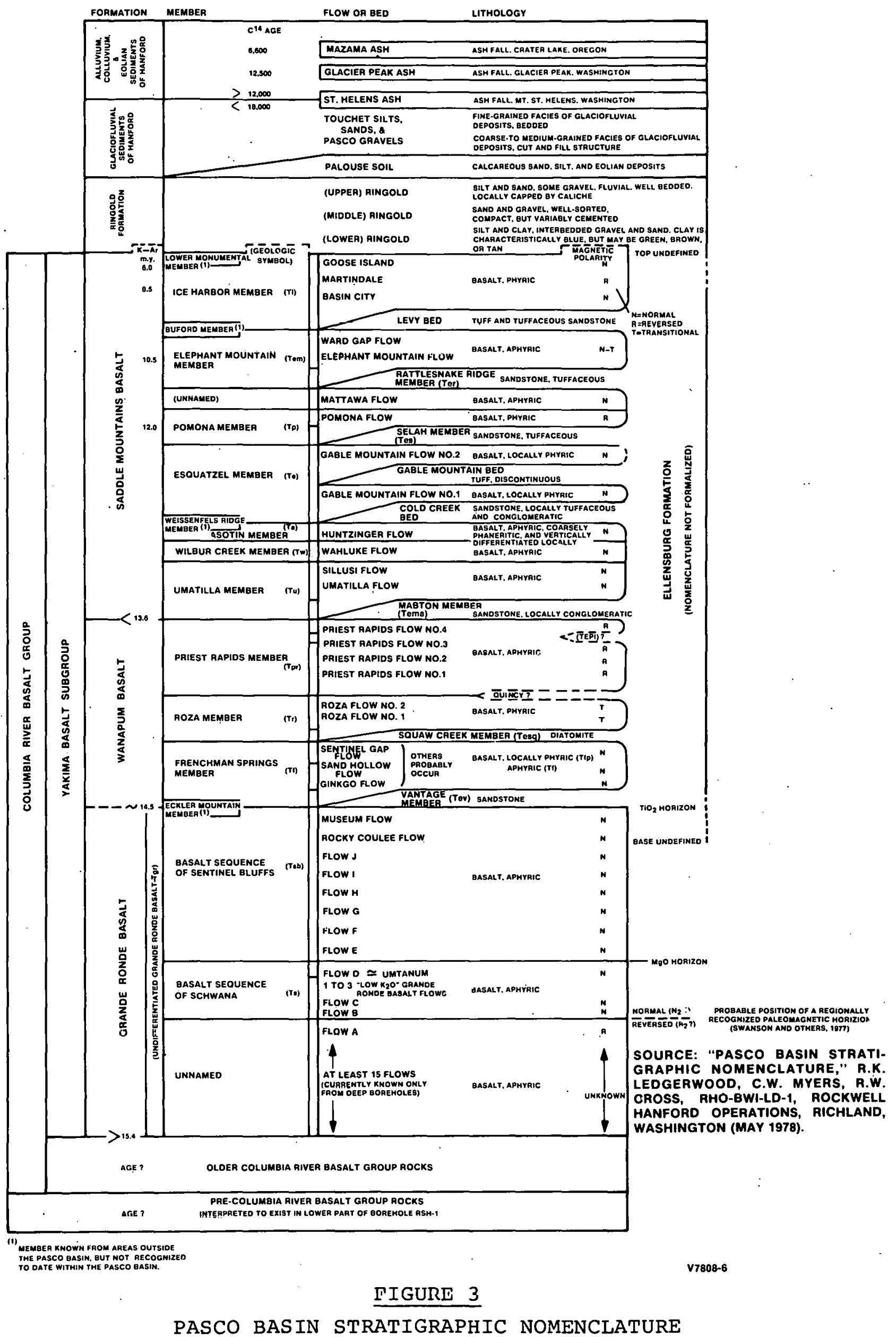


POMONA MEMBER

The Pomona Member is a slightly phyric basalt flow. The flow is medium to light gray and averages about 33 meters in thickness. Schmincke(11) has divided this flow into three zones: (1) a basal zone comprising less than one-third of the flow; (2) a central zone or entablature comprising the bulk of the flow; and (3) an upper zone comprising one-fifth of the flow thickness. The central zone or entablature is conspicuous for its long, continuous, undulating columns with diameters of 15-30 cm. Near the top, they cluster into composite columns, 1-2 meters wide which flare out from the center at high angles. (11)

The buckled surface of the Pomona flow is broken in many places into blocks of highly oxidized scoria. About $8 \mathrm{~km}$ west of Benton City, $300 \mathrm{~m}$ downstream from a power station (1 1) Schmincke has noted that the top of the flow has developed as a maze of more than six flow units separated by lenses of scoria and breccia.

Such units are rare and may be the result of extreme gushing and eddying of the lava due to topographic irregularities. Spectacular péperrites occur where the flow ploughed into the vitric tuff near the flow margin such as along crab creek in T.16N., R.28E., and at the Snake River in T.9N., R.32E.

The Pomona Member was defined by Schmincke (11) as the upper flow in the southern entrance of the Yakima River. Canyon $10 \mathrm{~km}$ north of Yakima, Washington, where it is well exposed in a U. S. Highway 97 road cut and in a nearby quarry (Figure 4). The Pomona Member was termed the Wenas or one of the Wenas flows, but incorrect application of this name caused the designation Wenas to be abandoned. 


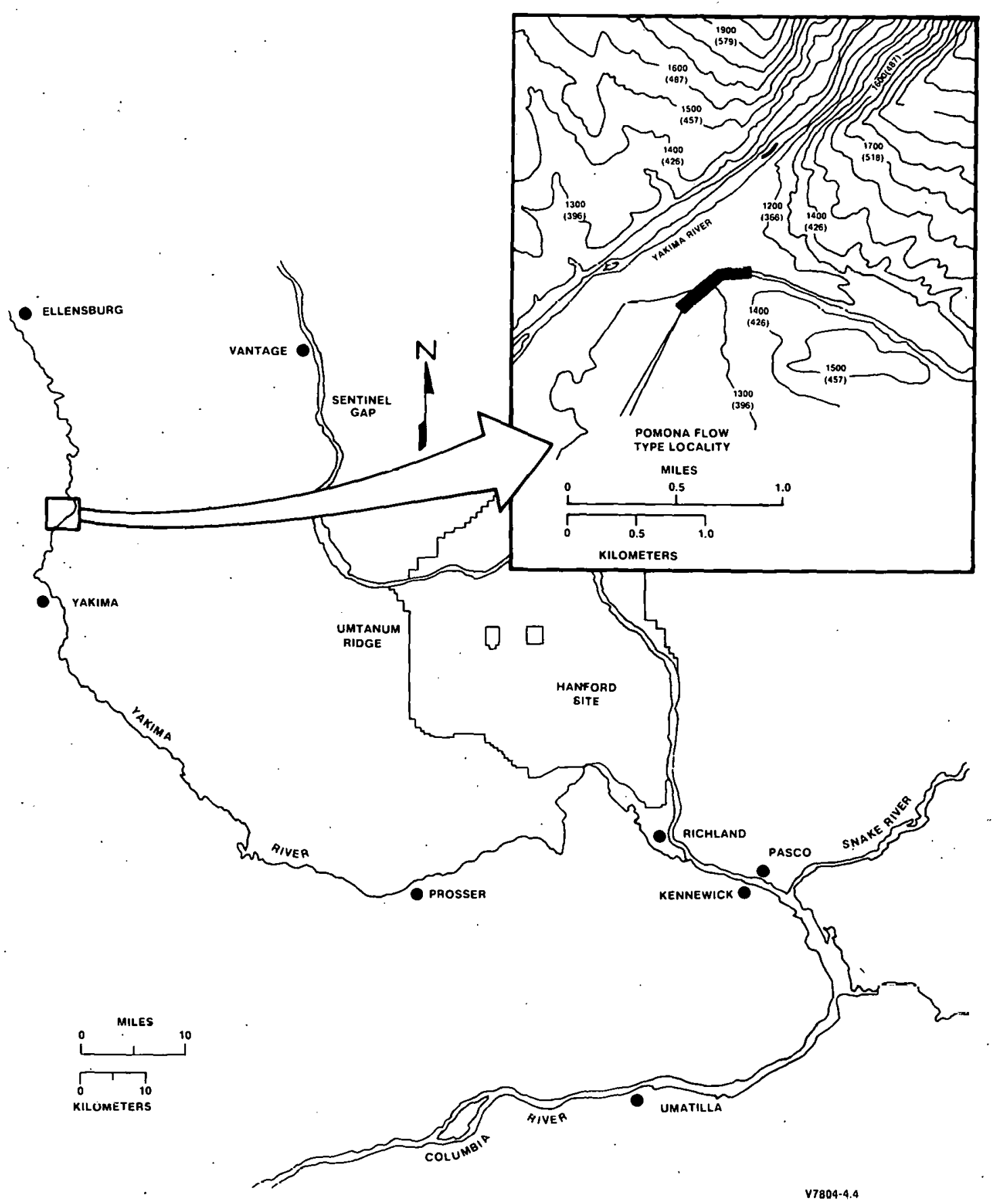

FIGURE 4

POMONA TYPE LOCALITY LOCATION MAP

(Contours in feet [meters] above mean sea level.) 
Figure 5 depicts an idealized section through the Pomona Member. The horizontal zones are separated by an abrupt contact (No. 5). The upper (No. 1) and basal (No. 3) zones correspond to upper and lower colonnades and the central zone (No. 2) to the entablature of Tomkeieff. (12) The upper zones are generally buckled (No. 12) at the top and may contain vesicles (No. 7) that coalesce into sheets. Undulating (No. 10) vertical joints divide the zone into thick (No. 4) prismatic columns. Other features sometimes observable in the Pomona Member include hackly columns (No. 7) fan jointing (No. 11) and pipe vesicles (No. 8).

The Pomona Member covers an area of about $18,000 \mathrm{~km}^{2}$ and the total volume of lava deposited is estimated as $540 \mathrm{~km}^{3}$. (11)

The Pomona Member is characterized petrographically by small phenocrysts of plagioclase (generally less than $5 \mathrm{~mm}$ long), clinopyroxene, and olivine. Modal analyses are distinctive because of low plagioclase/pyroxene ratios. (11) Plagioclase phenocrysts commonly have wedge-shaped appearance (Figure 6). Locally, as in a quarry on the east side of Devils Canyon, the flow contains large clots (up to $10 \mathrm{~cm}$ or more across) of plagioclase, pyroxene (including very rare hypersthene) and olivine believed to have formed during crystallization afler eruption. (This information was prepared by D. A. Swanson, U. S. Geological Survey, Menlo Park, California.) The detailed petrography of Pomona samples from the type section is given in Appendix A (prepared by A. C. Waters, Santa Cruz, California).

The Pomona Member has a characteristic intergranular texture although intersertal and hyalopilitic textures may occur in its most glassy parts. Most clinopyroxene is colorless, unlike that in other flows, but where it borders tachylyte, it is a pale brown, probably due to late enrichment in titanium or iron.

The physical and thermal properties of the Pomona flow have been reported in other papers. (13) Table VI summarizes recent results from core analyses of samples from within the Gable Mountain area, Hanford, Washington. 


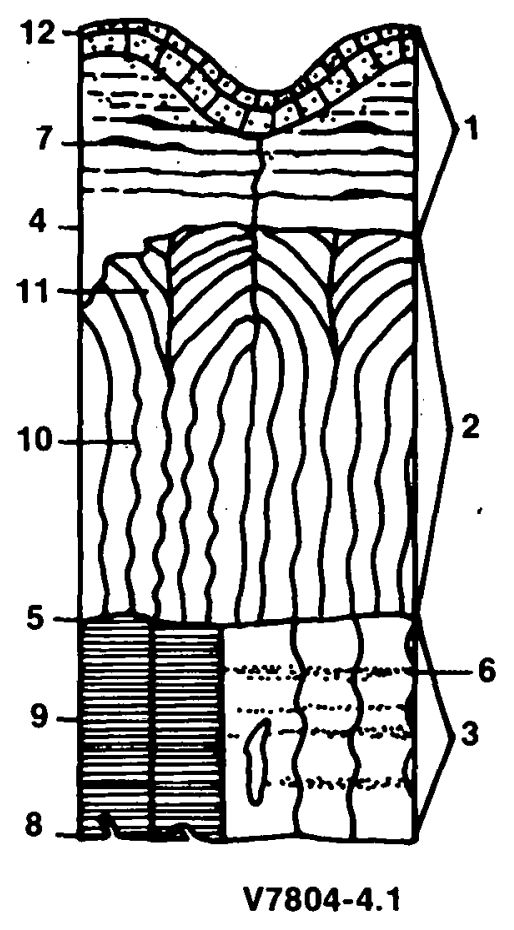

FIGURE 5

IDEALIZED SECTION THROUGH THE POMONA MEMBER 
POMONA

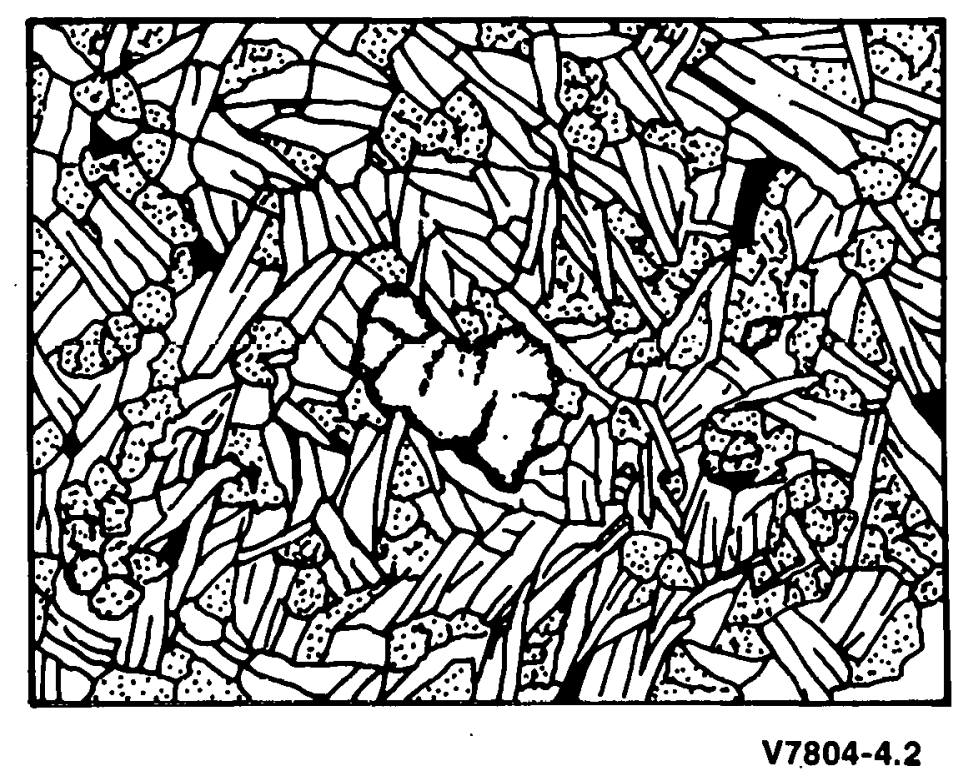

PLAGIOCLASE
ClINOPYROXENE
OLIVINE
OPAQUES

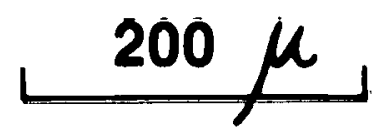

FIGURE 6

REPRESENTATIVE TEXTURE OF THE POMONA MEMBER 
TABLE VI

SUMMARY OF PHYSICAL AND THERMAL CHARACTERISTICS OF THE POMONA MEMBER

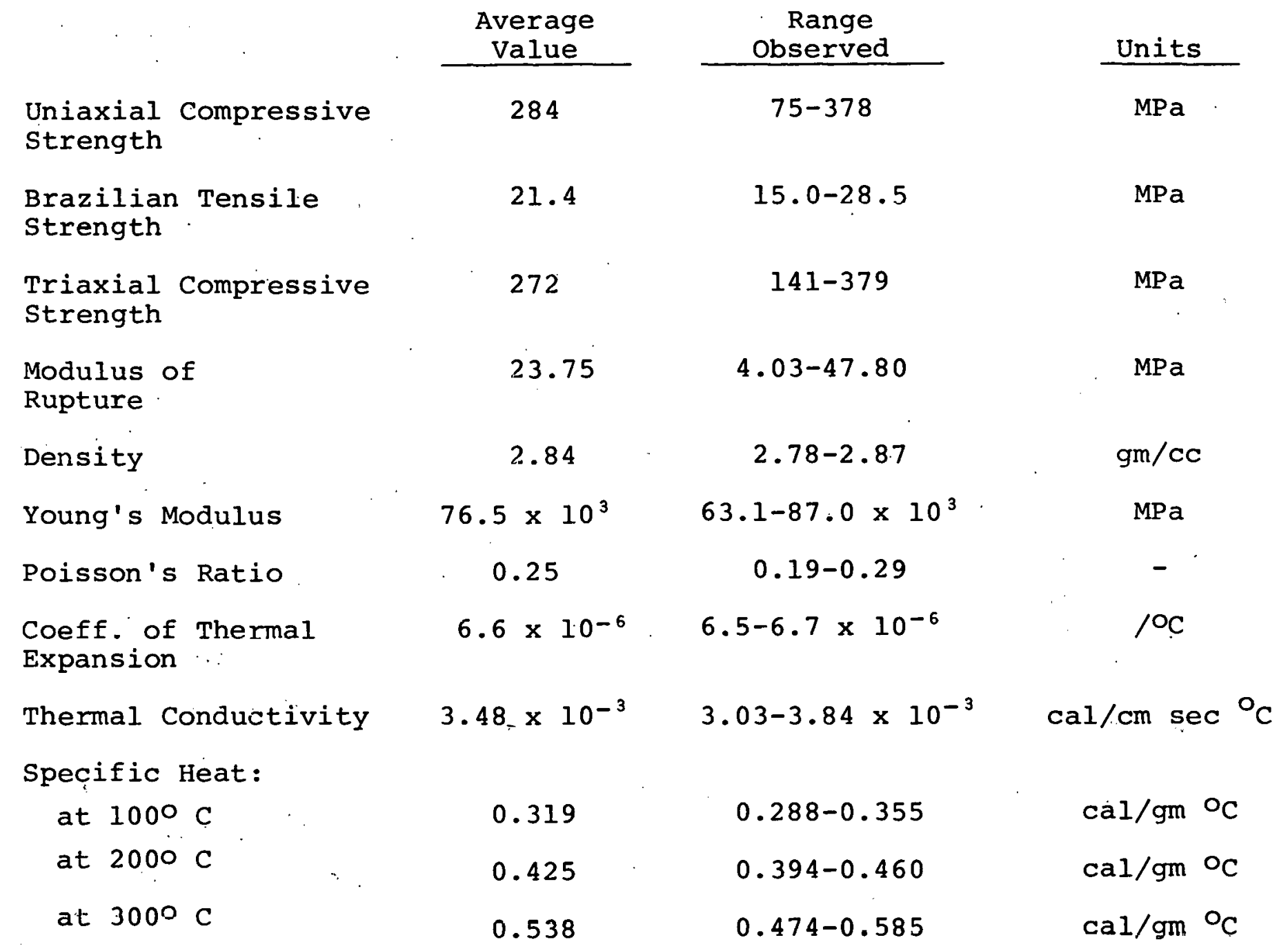


Chemically, the Pomona Member is characterized by high $\mathrm{CaO}, \mathrm{MgO}$ and chromium, but low FeO, $\mathrm{Fe}_{2} \mathrm{O}, \mathrm{TiO}_{2}$, hafnium, and barium. Its chemical composition is summarized in Appendix $B$ using data from existing drill holes (Figure B.1).

\section{UMTANUM UNIT}

The Umtanum Unit is an identified flow from the Basalt sequence of Schwana; Grande Ronde Rasalt Formation of the Columbia River Basalt Group. Unlike the Pomona Member, no type section has been described for the Umtanum Unit.. Exposures of it are found in Umtanum Ridge due west of the Hanford site and at Sentinel Gap (Figure 4). Samples of this flow have also been obtained from ar111 holes within the Hanfurd site.

The chemistry of the Umtanum Unit is summarized in Appendix B. The flow shows a very low Mgo content. Physically, the Umtanum Unit possesses excellent platy jointing at several levels. Petrographically, all of the rocks examined are high in glass, have small microlites, and have almost no microphenocrysts. The flow is very thick (in excess of 65 meters) and aphanitic. The platy jointing is probably the result of the stretching and smearing out of tiny vesicles and diktytaxitic patches, and infilling of the cavities by chlorophaeite, some of which has altered to clay, opal, and chalcedony. Petrographic description of drill hole samples from Wells $\mathrm{DDH}-3$ and $\mathrm{DH}-5$, within the Hanford Site, are given in Appendix B, Figure B.1, (prepared by A. C. Waters).

\section{BCR-1 STANDARD}

The designation of this sample stands for Basalt Columbia River-1 standard. The sample was initially collectcd by A. C. Waters from a quarry near Hood River, Oregon, This basalt was used as an international basalt reference sample by the Standards Committee of the Geochemical Society. Best values for constituents determined in a rock analysis and for trace elements were given by Flanagan. (14). 
Appendix D depicts the whole rock analyses for BCR-1 using $x$-ray fluorescence. These results were recently provided to us by Washington State University. Results on the trace element composition of $\mathrm{BCR}-1$ are shown in Appendix $\mathrm{D}$ from Flanagan. (14)

\section{WATERS}

Generally, waters from basaltic aquifers are characterized by high ratios of calcium-to-sodium and of magnesium-to-calcium, a relatively high silica content and a relatively high fluoride content.

La Sala and Doty (15) have examined numerous water analyses of Columbia Plateau basaltic aquifers. They concluded that the waters were typical of those found in sedimentary aquifers. The silica content of these waters indicates near equilibrium with a silica phase having properties similar to those of chalcedony or cristobalite. The silica probably comes into solution from feldspars and other minerals, but at a concentration higher than that at which it would be in equilibrium with quartz. $(16,17)$ The solubility of quartz is particularly low and would account for only 5 to $15 \mathrm{ppm} \mathrm{SiO}_{2}$ in the water. Other silicate minerals, however, have solubilities intermediate between quartz and amorphous silica (40 ppm).

Waters from deep aquifers underlying the Hanford Site have recently been analyzed.(18) The location of well samples is shown in Figure 7. Results of the analysis of Wells $\mathrm{DB}-1$, DB-2, DB-7, and RSH-1 are summarized in Tables VII and VIII. The major constituents of these waters are depicted using semilogarithmic diagrams in Figures 8-11, respectively. The equilibrium $\mathrm{pH}$ with respect to $\mathrm{CaCO}_{3}$ of all these waters is higher than the actual pH. The results from the analyses are also fairly close in the duplicate samples. 


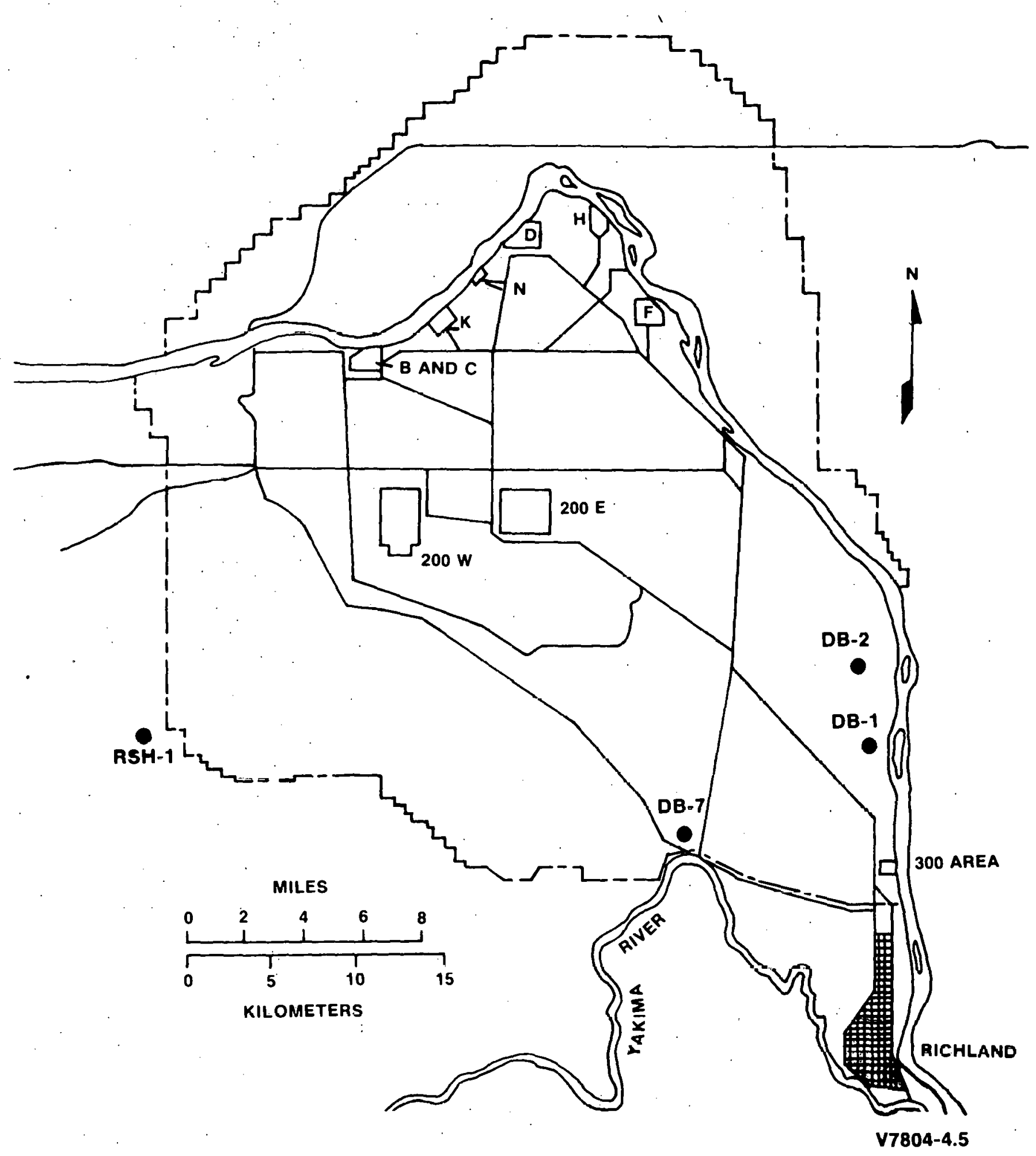

\section{FIGURE 7}

HANFORD AREA MAP SHOWING LOCATION OF WELLS SAMPLED 
TABLE VII

MAJOR CONSTITUEINT: ANALYTICAL RESULTS

(Sampling Dates are in Parentheses)

\begin{tabular}{|c|c|c|c|c|c|c|c|c|c|}
\hline & \multicolumn{2}{|c|}{$\begin{array}{c}\text { DB-1 } \\
(8 / 9 / 76)\end{array}$} & \multicolumn{2}{|c|}{$\begin{array}{c}D B-2 \\
(8 / 17 / 76)\end{array}$} & \multicolumn{2}{|c|}{$\begin{array}{c}\text { DB-7 } \\
(8 / 11 / 76)\end{array}$} & \multicolumn{2}{|c|}{$\begin{array}{c}\text { RSH-1 } \\
(5 / 11 / 77)\end{array}$} & Units \\
\hline$\frac{\text { Constituent }}{\mathrm{SiO}_{2}}$ & 27.8 & 28.8 & 31.6 & 31.8 & 36.4 & 36.4 & 22.5 & 22.5 & ppm \\
\hline $\mathrm{Na}$ & 75.0 & 75.0 & 150.0 & 150.0 & 106.0 & 117.0 & 30.0 & .25 .0 & ppm \\
\hline K & 14.0 & 14.0 & 12.5 & 12.5 & 12.5 & 12.5 & 9.0 & 7.7 & ppm \\
\hline $\mathrm{Ca}$ & 3.5 & 8.0 & 4.2 & 4.5 & 2.5 & 2.5 & 6.5 & 8.5 & ppm \\
\hline $\mathrm{Mg}$ & 0.70 & 0.90 & 0.18 & 0.20 & 0.50 & 0.50 & 1.0 & 2.2 & ppm \\
\hline $\mathrm{Fe}$ & .155 & .105 & 0.53 & 0.63 & 2.72 & 3.82 & .08 & $<.02$ & ppm \\
\hline $\mathrm{HCO}_{3}$ & 208.8 & 219.6 & 196.4 & 192.8 & 135.7 & 121.4 & 42.8 & 67.3 & $\mathrm{mg} / \ell \mathrm{CaCO}_{3}$ \\
\hline $\mathrm{CO}_{3}$ & 0 & 0 & 21.4 & 21.4 & 35.7 & 50.0 & 0 & 0 & $\mathrm{mg} / \mathrm{l} \mathrm{CaCO}_{3}$ \\
\hline $\mathrm{SO}_{4}$ & $<.5$ & $<.5$ & .5 & .5 & 1.0 & .5 & 23.0 & 15.0 & ppm \\
\hline $\mathrm{Cl}$ & 12.2 & 11.8 & 134.5 & 117.5 & 53.0 & 52.0 & 16.2 & 8.8 & ppm \\
\hline $\mathrm{F}$ & 3.0 & 3.5 & 2 & $<1$. & 7.0 & 8.7 & 0.7 & 0.7 & ppin \\
\hline NO & .5 & .5 & $<.5$ & $<.5$ & .5 & .5 & $<.05$ & $<.20$ & ppm \\
\hline B & .25 & .25 & .6 & .6 & .8 & .7 & $<.05$ & $<.05$ & ppm \\
\hline T.D.S. & 345 & 307 & 430 & 417 & 531 & 505 & 118 & 112 & $\mathrm{mg} / \mathrm{l}$ \\
\hline TOC & 29 & 28 & 14 & 16 & 27 & 28 & 9 & 9 & $\mathrm{mg} / \mathrm{l}$ \\
\hline Cond. & 400 & 430 & 430 & 440 & 450 & 475 & 250 & 250 & $\mathrm{micromhos} / \mathrm{cm}$ \\
\hline $\mathrm{pH}$ & 8.2 & 8.3 & 8.6 & 8.6 & 9.0 & 9.0 & 7.3 & 7.4 & \\
\hline & $\begin{array}{l}\text { Water fro } \\
\text { interbed } \\
\text { with cent } \\
\text { punp }\end{array}$ & $\begin{array}{l}\text { Mabton } \\
\text { ampled } \\
\text { ifugal }\end{array}$ & $\begin{array}{l}\text { Water fr } \\
\text { interbed } \\
\text { with air } \\
\text { device a } \\
\text { compress }\end{array}$ & $\begin{array}{l}\text { n Mabton } \\
\text { sampled } \\
\text { ift } \\
\text { air } \\
\end{array}$ & $\begin{array}{l}\text { Water } \\
\text { interbe } \\
\text { with ai } \\
\text { device } \\
\text { campres }\end{array}$ & $\begin{array}{l}\text { m Mabton } \\
\text { sampled } \\
\text { ift } \\
\text { d air } \\
r\end{array}$ & $\begin{array}{l}\text { Water } f \\
\text { Ronde Fy } \\
\text { by swabl }\end{array}$ & $\begin{array}{l}\text { n Grande } \\
\text { sampled } \\
\text { ig }\end{array}$ & • \\
\hline
\end{tabular}


TABLE VIII

TRACE CONSTITUENTS: ANAEYTICAL RESULTS*

(Sampling Dates are in Parentheses)

\begin{tabular}{|c|c|c|c|c|c|c|c|c|}
\hline \multirow{2}{*}{$\frac{\text { Constituent }}{\mathrm{Zn}}$} & \multicolumn{2}{|c|}{$\begin{array}{c}D B-1 \\
(8 / 9 / 76) \\
\end{array}$} & \multicolumn{2}{|c|}{$\begin{array}{c}\mathrm{DB}-2 \\
(8 / 17 / 76) \\
\end{array}$} & \multicolumn{2}{|c|}{$\begin{array}{c}\mathrm{DB}-7 \\
(8 / 11 / 76) \\
\end{array}$} & \multicolumn{2}{|c|}{$\begin{array}{c}\text { RSH-1 } \\
(5 / 11 / 77) \\
\end{array}$} \\
\hline & 24 & 16 & 14 & 15 & 600 & 655 & 2560 & 39000 \\
\hline $\mathrm{Cu}$ & 15 & 15 & 10 & 12 & 15 & 19 & 20 & 50 \\
\hline $\mathrm{Hg}$ & $<.05$ & $<.05$ & $<.05$ & $<.05$ & $<.05$ & $<.05$ & $<.05$ & $<.05$ \\
\hline $\mathrm{Sb}$ & 10 & $<8$ & $<8$ & $<0$ & 10 & 15 & $<3$ & $<3$ \\
\hline $\mathrm{Ba}$ & 22 & 30 & 39 & 35 & 43 & 42 & 140 & 50 \\
\hline Re & 8 & $.9^{\circ}$ & 1.3 & 1.2 & .8 & 1.2 & NA & NA \\
\hline $\mathrm{Cd}$ & $<.5$ & $<.5$ & $<.5$ & $<.5$ & 1.0 & 1.5 & .2 & .6 \\
\hline $\mathrm{Cr}$ & 2 & $<1$ & $<1$ & $<1$ & 14 & 33 & $<25$ & $<25$ \\
\hline Co & 6 & 7 & 7 & 5 & 6 & 5 & 2 & 2 \\
\hline $\mathrm{Pb}$ & 19 & 17 & 15 & 13 & 31 & 41 & 7 & 12 \\
\hline Mo & 67 & 20 & $<1$ & $<1$ & 40 & 15 & 2 & 2 \\
\hline $\mathrm{Nj}$ & 7 & 10 & 8 & 11 & 15 & 1.3 & $\mathrm{NA}$ & $\mathrm{NA}$ \\
\hline $\mathrm{Ag}$ & 1.5 & 1.0 & 1.0 & 1.5 & 0.8 & 0.8 & $<2.5$ & $<2.5$ \\
\hline Sr & 7 & 5 & 2 & 3 & 4 & 3 & $\mathrm{NA}$ & $\mathrm{NA}$ \\
\hline $\mathrm{Sn}$ & 14 & 17 & 14 & 14 & 5 & 5 & NA & $\mathrm{NA}$ \\
\hline $\mathrm{Tl}$ & 11 & 11 & 12 & 15 & 11 & 13 & $\mathrm{NA}$ & NA \\
\hline $\mathrm{V}$ & $<2$ & $<2$ & 8 & 9. & 13 & 14 & NA & NA \\
\hline Unit Sampled & Mabton & nber & Mabton & Member & Mabton & Member & & $\begin{array}{l}\text { le Ronde } \\
\text { nation }\end{array}$ \\
\hline
\end{tabular}

*All constituents are expressed in parts per billion. NA Not analyzed for. 


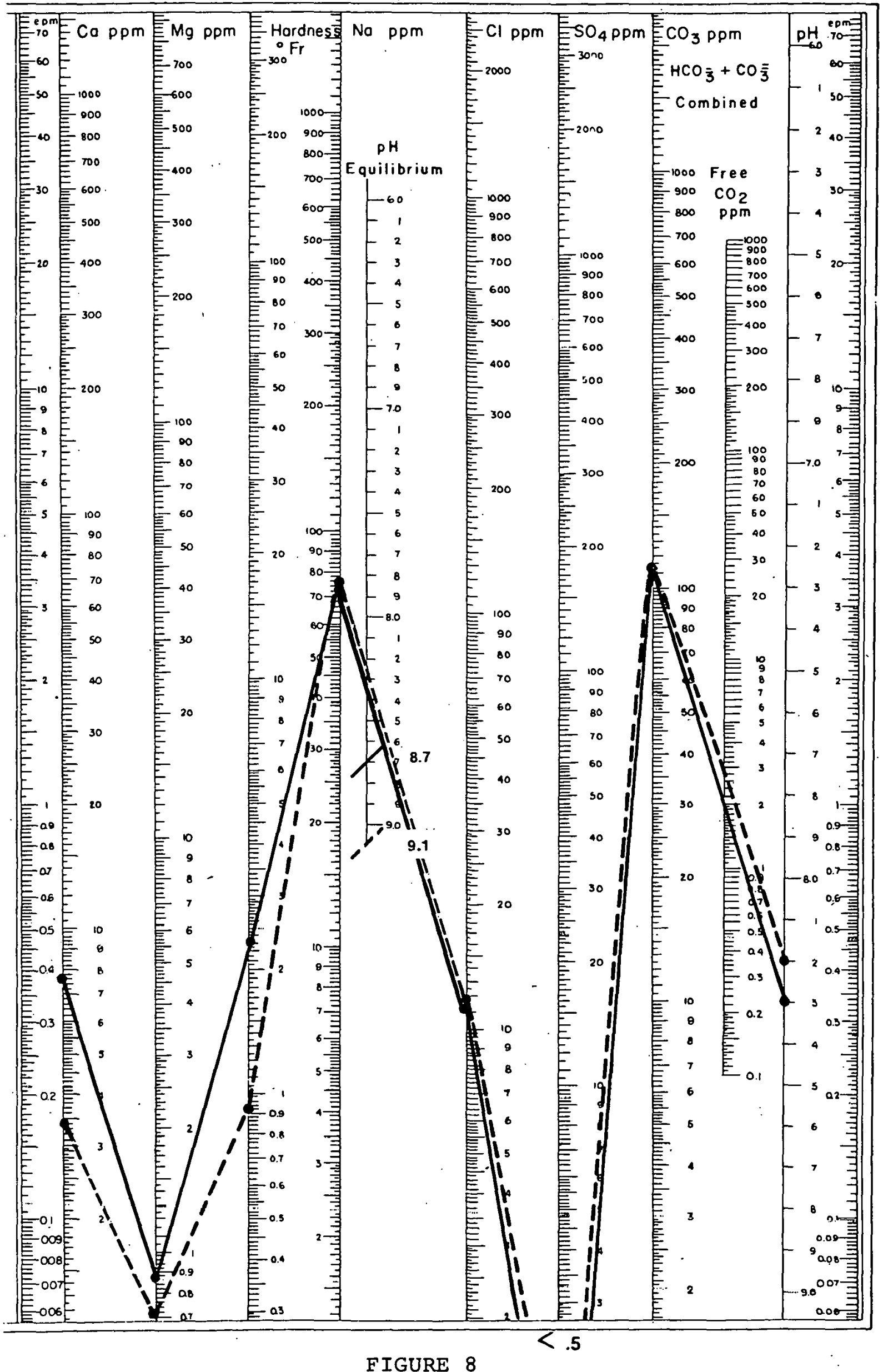

FIGURE 8 


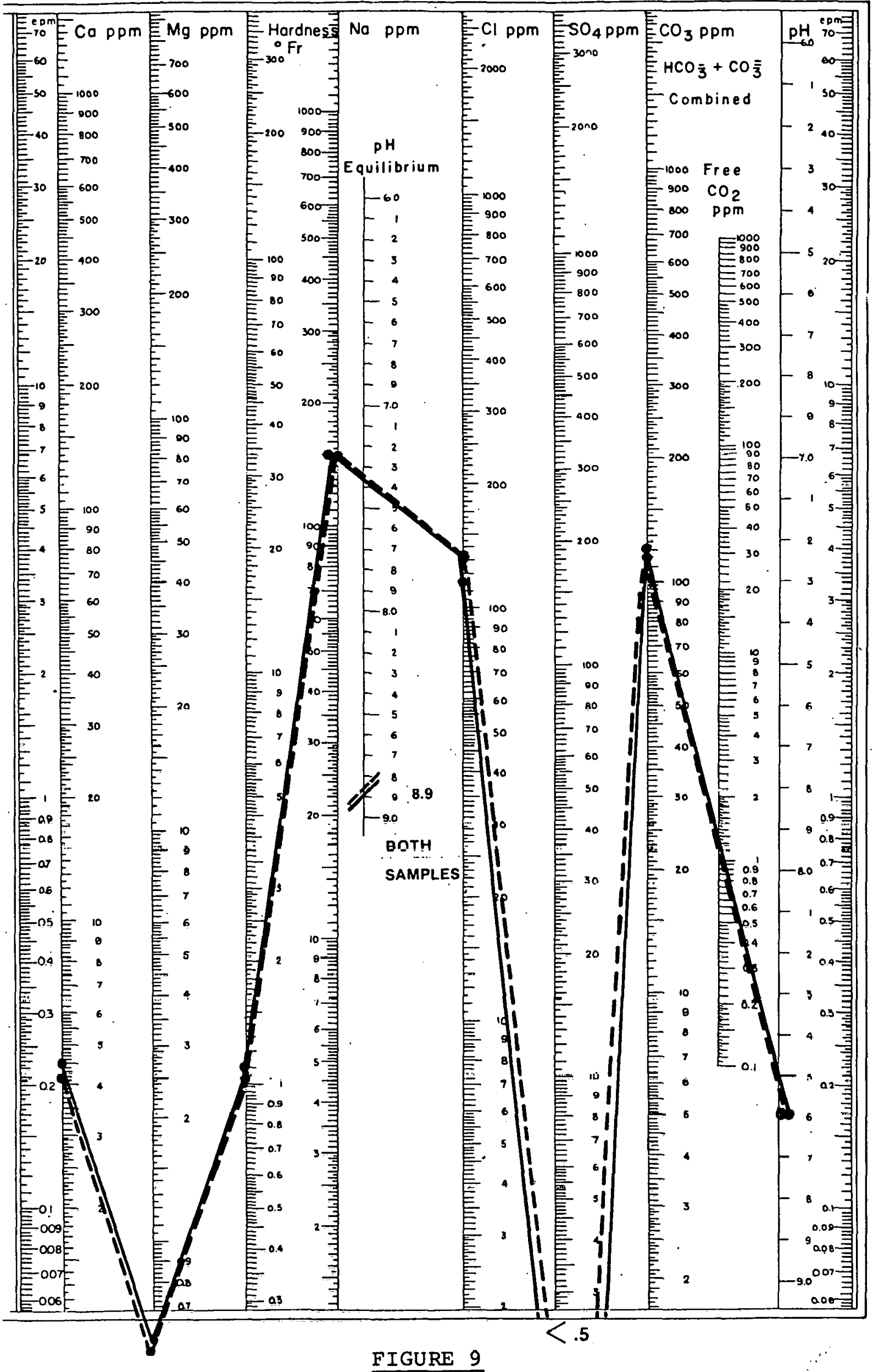




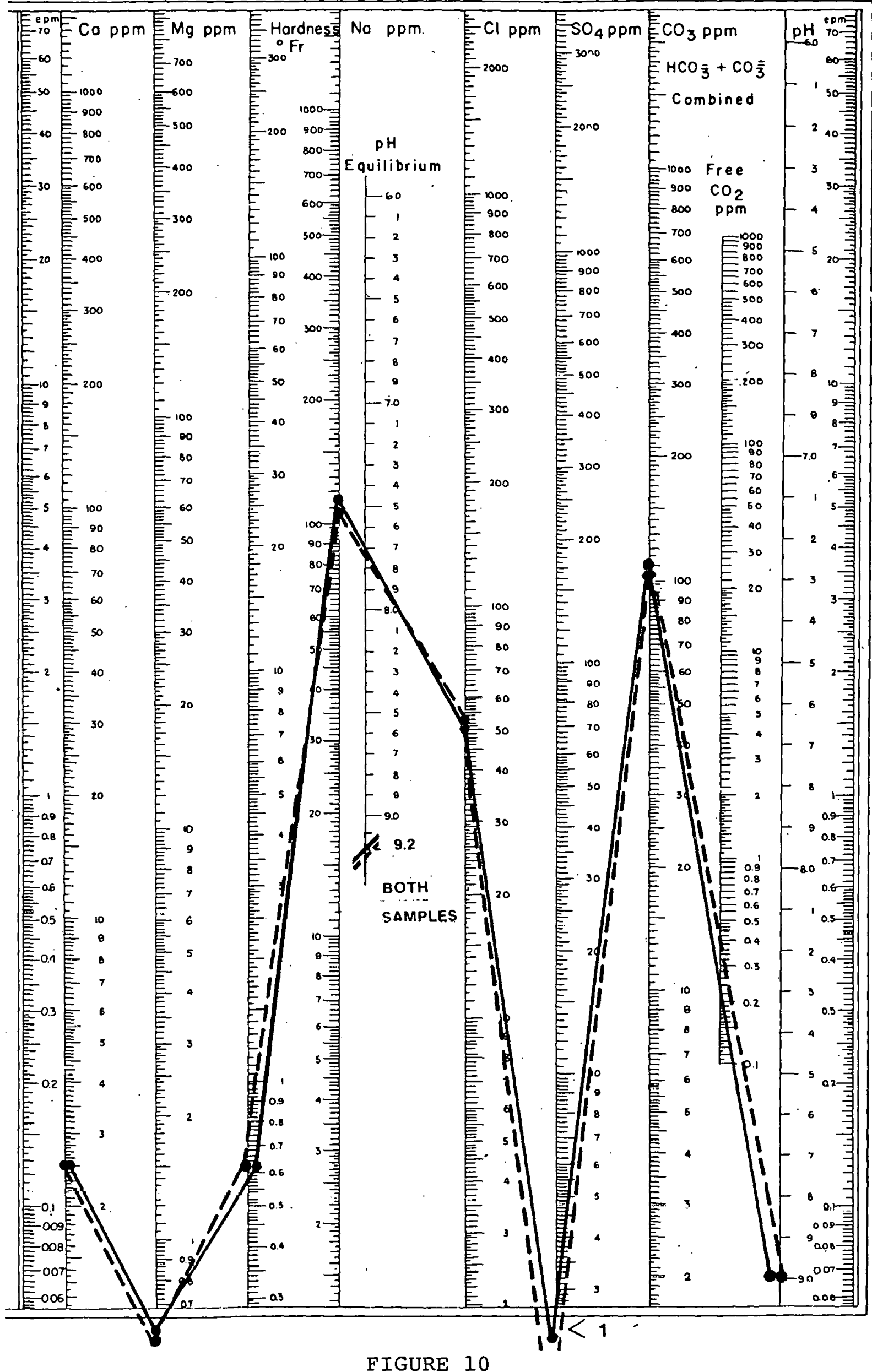




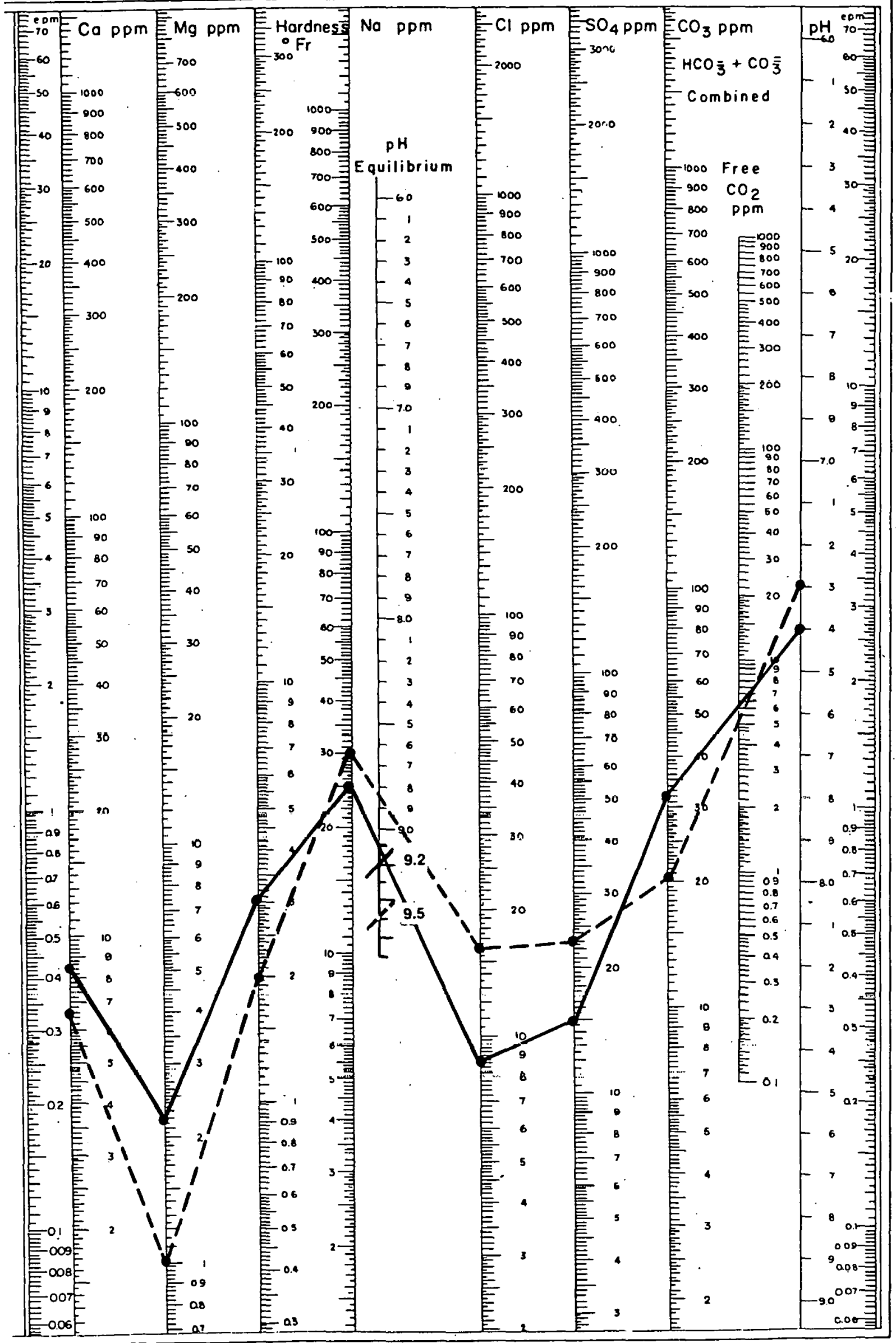

FIGURE 11 
Application of the Palmer classification (18) to the waters from $\mathrm{DB}-1, \mathrm{DB}-2, \mathrm{DB}-7$, and $\mathrm{RSH}-1$ shows that all the waters are Class I waters and in the bulk of the samples, the primary alkalinity is dominant, indicating waters in contact with sedimentary strata. Well DB-7 shows also a high primary. salinity, probably due to the basaltic influence on the water composition.

In the waters depicted in Figures 8-11, sodium is the predominant cation present. These waters appear to be in equilibrium with a feldspar of about equal calcium and sodium content.

The cation-anion balances of the waters from $\mathrm{DB}-1, \mathrm{DB}-2$, $\mathrm{DB}-7$, and $\mathrm{RSH}-1$ are within 0.8-14.8 percent, averaging 5.5 percent. In over 60 percent of the samples, the balance is within 2 percent.

The main trace constituents are $\mathrm{Zn}, \mathrm{Cu}, \mathrm{Ba}, \mathrm{Pb}$, and $\mathrm{Mo}$. Zinc is present in concentrations as high as $39 \mathrm{ppm}$ (RSH-1 sample).

\section{ENGINEERED BARRIERS}

The present concept is to enclose spent unreprocessed fuel in a container constructed of stainless steel after the spent unreprocessed fuel has cooled in a water pool for five to ten years. The container would serve only to permit handling and temporary storage of 50 years.

The term "overpack" refers to the material emplaced between the borehole wall and the canister. At present, the spent unreprocessed fuel stored in a repository must be retrievable, and overpacks should be engineered that permit retrieval of the spent unreprocessed fuel. However, long-term storage will reguire a permanent overpack. 
There is considerable promise for further research into canister materials design for long-term containment or isolation of radionuclides (i.e., approximately $10^{6}$ years).

There is a need for much further research into overpack materials selection and design for long-term containment of radionuclides. Opportunities for the design of an effective overpack barrier are promising.

The functions of the overpack should be as follows:

Chemical Functions

- Must absorb leaking nuclides;

- Should control oxidation potential and $\mathrm{pH}$ to limit solubility of nuclides;

- should react chemically with migrating nuclides to minimize solubility;

- could act as a dehydrating agent, preventing access of water to the waste;

- Should provide protection from corrosion to the container.

\section{Physical Functions}

- should act as a heat transfer medium;

- Should provide stress relief (both static and dynamic);

- Should act as a permeability barrier;

- Should act as radiation shield and permit inspection above the storage well during the initlal storage period.

Several container materials are presently being studied by investigators abroad. These include hot pressed $\mathrm{Al}_{2} \mathrm{O}_{3}$ and copper. The swedish government has indicated an intention to use a copper container. Overpacks may include one or more of the following: 
- Layer silicates;

- Zeolites;

- Concrete;

- Eh-pH buffer pairs; e.g., $\mathrm{CuS}_{2}$-Cus, NiO-FeO;

- $\mathrm{pH}$ buffers, e.g., carbonates;

- silica-alumina gels

Overpack materials should be tailored only to prevent the migration of radionuclides that would possess a high mobility through the host rock environment and could not otherwise be contained.

\section{SCENARIOS TO BE MODELED}

During the first few decades of geologic isolation, the heat of radioactive decay in the wastes could raise considerably the immediate repository temperature. Temperatures significantly above the normal $40-45^{\circ} \mathrm{C}$ ambient for deep repository would persist for up to several hundred years depending on the placement of the waste containers and the thermal conductivity of the host rock. If ground water should come in contact with waste sealed in a repository during this thermal period of isolation, reactions would be expected.

The expectation is that hydrothermal solutions would transport species to and from the waste solid and the host rock, a process very similar to contact metamorphism. The result would be a zone around the waste container, a contact aureole, in which there would be developed new "minerals" which might or might not correspond to known mineral species. The thickness of the aureole would be limited by the falloff of temperature away from the container. T'he phases in the aurcolc would depend primarily on the compositions of the waste form and of the repository rock with perhaps some contribution from the container and overpack. These phases could provide either 
better or worse long-term fixation depending on their solubility in percolating ground water. Largely crystalline waste solids would react more slowly than poorly crystalline or noncrystalline solids such as glasses; yet, unless they were in thermodynamic equilibrium with the pressure-temperaturechemical environment of the waste repository site, they too should eventually interact.

Once the thermal period (200-600 years) is over, the mixture of these interaction products and the remnants of the waste form and its containment would constitute a "new" waste form. It is this "new" waste form which will act as a source of radionuclides for any additional transport over the functional lifetime of the repository.

To simulate the behaviór during the operating and postoperating phases of a repository, waste/basalt interaction studies must be conducted using the experimental conditions noted in Table IX. These experiments will involve typical Columbia River Basalt waters in flooded or wet areas and container materials as needed. The results of the studies should then be used to determine the types of overpack needed to contain any radionuclides that would otherwise migrate through the environment and cause a higher than maximum permissible concentration to get to the biosphere. 
TABLE IX

EXPERIMENTAL CONDITIONS FOR

WASTE/BASALT COMPATIBILITY EVALUATIONS

\begin{tabular}{|c|c|c|c|}
\hline & $\begin{array}{l}\text { Dry Repository } \\
\left(\mathrm{H}_{2} \mathrm{O} \text { from Minerals on } 1 y\right)\end{array}$ & $\begin{array}{l}\text { Wet Repository } \\
\text { Low Transport } \\
\text { (Closed System) }\end{array}$ & $\begin{array}{l}\text { Flooded Repository } \\
\text { High Transport } \\
\text { (Open System) }\end{array}$ \\
\hline $\begin{array}{l}\frac{\text { LOW PRESSURE }}{\text { (No Lithostatic }} \\
\text { LOad) } \\
\text { P } 1 \text { Bar } \\
\text { Open to Atmosphere }\end{array}$ & \begin{tabular}{|c|}
\multicolumn{1}{c}{ A } \\
Experimental Method \\
Sealed Gold or Glass \\
Ampuls \\
1. Waste + Basalt \pm Metal \\
2. Speciflc Mineral \\
Syotems \pm Metal
\end{tabular} & $\because$ & $\begin{array}{l}\text { B } \\
25-90{ }^{\circ} \mathrm{C}- \\
\text { Experimental Method } \\
\text { Water Circulating Through } \\
\text { Columns of Waste/Basalt } \\
\text { 1. Waste }+ \text { Basalt }+\mathrm{H}_{2} \mathrm{O} \\
\pm \text { Metal } \\
\text { 2. Speciflc Mlneral } \\
\text { Systems }+\mathrm{H}_{2} \mathrm{O}^{\circ} \pm \text { Metal }\end{array}$ \\
\hline $\begin{array}{l}\text { HIGH PRESSURE } \\
P=50-500 \text { Bars } \\
\text { Sealed Repository }\end{array}$ & \begin{tabular}{|c|}
$c$ \\
Experimental Method \\
Hydrothermal: Cold \\
Seal or Morey Vessels \\
1. Waste + Basalt \pm Metal \\
2. Specific Mineral \\
Systems \pm Metal
\end{tabular} & $\begin{array}{l}\text { D } \\
50-400{ }^{\circ} \mathrm{C}- \\
\text { Experimental Method } \\
\text { Hydrothermal : Cold } \\
\text { Seal or Morey Veosels } \\
\text { 1. Waste }+ \text { Basalt }+\mathrm{H}_{2} \mathrm{O} \\
\pm \text { Metal } \\
\text { 2. Specific Mineral } \\
\text { Systems }+\mathrm{H}_{2} \mathrm{O} \pm \\
\text { Metal }\end{array}$ & \begin{tabular}{l}
\multicolumn{1}{c}{$50-400{ }^{\circ} \mathrm{C}-$} \\
$\begin{array}{l}\text { Experimental Method } \\
\text { Circulating Water Hydro- } \\
\text { thermal }\end{array}$ \\
$\begin{array}{l}\text { 1. Waste }+ \text { Basalt }+\mathrm{H}_{2} \mathrm{O} \pm \\
\text { Metal }\end{array}$ \\
2. Specific Mineral \\
Systems $+\mathrm{H}_{2} \mathrm{O} \pm$ Metal
\end{tabular} \\
\hline
\end{tabular}




\section{REFERENCES}

1. G. J. McCarthy and M. W. Grutzeck, Preliminary Evaluation of the Characteristics of Nuclear Wastes Relevant to Geologic Isolation in Basalt, RHO-C-12, Rockwell Hanford Operations, Richland, Washington (May 1978).

2. W. A. Ross, Development of Glass Formulations Containing High-Level Nuclear Wastes, PNL-2481, Pacific Northwest Laboratory, Richland, Washing̣ton (February 1978).

3. J. E. Mendel, et al., A Program Plan for Comprehensive Characterization of Solidified High-Level Wastes, BNWL-1940, Battelle, Pacific Northwest Laboratories, Richland, Washington (December 1975).

4. J. E. Mendel, et al., Annual Report on the Characterization of High-Level Waste Glasses, BNWL-2252, Battelle, Pacific iNorthwest Laboratories, Richland, Washington (June 1977).

5. w. J. Gray, Volatility of a Zinc Borosilicate Glass Containing Simulated High-Level Radioactive Waste, BNWL-2111, Battelle, Pacific ivorthwest Laboratories, Richland, Washington (October 19\%).

6. R. P. Turcotte and J. W. Wald, Devitritication Behavior in a Zinc Borosilicate Nuclear Waste Glass, PNL-2247, Pacific Northwest Laboratory, Richland, Washington (May 1978).

7. W. A. Ross, et al., Annual Report on the Characterization of High-Level Waste Glasses, PNL-2625, Pacific Northwest Laboratory, Richland, Washington (June 1978).

8. G. J. McCarthy, et al., Simulated High-Level Waste-Basalt Interaction Experiments, second Interim Progress Report, RHO-BWI-LD-16, Rockwell Hanford Operations, Richland, Washington (June 30,1978 ).

9. B. L. Cohen, "The Disposal of Radioactive Wastes from Fission Reactors," Scientific American, 236 (6), 21, (1977). 
10. D. A. Swanson, "Yakima Basalt of the Tieton River Area, South-Central Washington," Geol. Soc. America Bul1., 78 pp. 1077-1110 (1967).

11. H. U. Schmincke, "Stratigraphy and Petrography of Four Upper Yakima Basalt Flows in South-Central Washington," Geol. Soc. America Bul1., 78, pp. 1385-1422 (1967).

12. S. I. Tomkeieff, "Basalt Lavas of the Giant's Causeway," Bul1. Volcanol: 2, p. 81-147, (1940).

13. W. I. Duvall, R. J. Miller, and F. D. Wang, Preliminary Report on Physical and Thermal Properties of Basalt Drill Hole DC-10 Pomona Flow - Gable Mountain, RHO-BWI-C-11, Rockwell Hanford Operations, Richland, Washington (May 1978).

14. F. J. Flanagan, "1972 Values for International Geochemical Reference Samples," Geochimica et Cosmochimica Acta, 37, pp. 1189-1200, (1973).

15. A. M. La Sala, Jr. and G. C. Doty, Preliminary Evaluation of Hydrologic Factors Related to Radioactive Waste Storage in Basaltic Rocks at the Hanford Reservation, Washington, U. S. Geological Survey Open-File Report (1971).

16. J. A. Lier, "The Solubility of Quartz," Utrecht, Kemink en Zoon, 54 pp., (1959).

17. G. W. Morey, R. O. Fournier, and J. J.. Rowe, "The Solubility of Quartz in Water in the Temperature Interval from 25 to $300^{\circ} \mathrm{C}, "$ Genchim.: et Cosmochim, Acta, 26, pp. 1029-1043.

18. R. A. Deju, Preliminary Analysis of Some Waters From the Confined Aquifers Underlying the Hanford Site, RHO-BWI-LD-12 Rockwell Hanford Operations, Richland, Washington (September 1978). 


\section{DISTRIBUTIION}

Number of
Copies

2

1

3

2

2

1

38

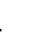

\section{LAWRENCE BERKELEY LABORATORY}

$$
\begin{array}{ll}
\text { J. C. Apps } \\
\text { L. }
\end{array}
$$

PACIFIC NORTHWEST LABORATORY

J. R. Serne

THE PENNSYLVANIA STATE UNIVERSITY

G. J. McCarthy

U. S. DEPARTMENT OF ENERGY-HEADQUARTERS

M. W. Frei

D. L. Vieth

U. S. DEPARTMENT OF ENERGY-RICHLAND

OPERATIOINS OFFICE

R. B. Goranson

D. J. Squires

A. C. WATERS

ROCKWELL HANFORD OPERATIONS

H. Babad

R. L. Biggeretaff

D. J. Brown

D. . T, ronkeram

T. A. Curran

R. A. Deju

H. B. Dietz

G. C. Evans

M. R. Fox

R. E. Gephart

R. J. Gimera

R. E. Isaacson

A. D. Krug

R. K. Ledgerwood

P. E. Long

J. F. Marron

M. J. Smith

W. W. Schulz

R. T. Wilde

Basalt Waste Isolation Program Library (15) Document Control (4) 


\section{APPENDIX A}

PETROGRAPHIC DESCRIPTION OF THE POMONA TYPE SECTION 
PETROGRAPHIC DESCRIPTION OF THE POMONA TYPE SECTION

Latitude $-46^{\circ} 42^{\circ} \mathrm{N}$
Longitude $-120^{\circ} 28^{\circ} \mathrm{W}$

SAMPLE A-1270 - (Taken from 8 feet below the flow top) Description

Numerous cumulate-like clots of plagioclase, as well as separate phenocrysts of the two minerals in the same size range: plagioclase, 0.5 to $1 \mathrm{~mm}$; pyroxene 0.3 to $0.6 \mathrm{~mm}$. This thin section has caught only a few segments of the large phenocrysts with poikilitic inclusions of pyroxene in the center of the plagioclase, which are one major characteristic of the Pomona Flow. The sliced parts of these phenocrysts are not larger than sliced sections of some of the microphenocrysts. Microlites of plagioclase are mostly 0.1 to $0.2 \mathrm{~mm}$ long; pyroxene microlites 0.05 to $0.1 \mathrm{~mm}$. Olivine rare, saponitized on edges and in cracks. Much black dusty tachylyte. Iron ores are in the tachylyte. Opal fills some small vesicles, others are empty. Opal appears to replace a rim of earlier chlorophaeite in some vesicles.

\section{POINT COUNT (1000 POINTS)}

\begin{tabular}{|c|c|c|c|c|c|c|}
\hline \multirow[b]{2}{*}{ Minerals } & \multirow{2}{*}{\multicolumn{2}{|c|}{ - Volume $\frac{4}{6}$}} & \multicolumn{4}{|c|}{ FOLIIL } \\
\hline & & & \multicolumn{2}{|c|}{ Ist 500} & \multirow[t]{2}{*}{ 2nd } & \multirow{2}{*}{$\frac{500}{166}$} \\
\hline Plagioclase & & 33.9 & & 173 & & \\
\hline $\begin{array}{l}\text { Phenocrysts } \\
\text { Microphenocrysts } \\
\text { Microlites }\end{array}$ & $\begin{array}{r}1 \cdot 6 \\
6.5 \\
25.8\end{array}$ & & $\begin{array}{r}8 \\
33 \\
132\end{array}$ & & $\begin{array}{r}8 \\
32 \\
126\end{array}$ & \\
\hline pyroxene & & 37.2 & & $1 \%$ & & 193 \\
\hline $\begin{array}{l}\text { Microphenocrysts } \\
\text { Microlites }\end{array}$ & $\begin{array}{r}0.7 \\
36.5\end{array}$ & & $174^{5}$ & & $\begin{array}{r}2 \\
191\end{array}$ & \\
\hline Olivine (fresh) & & 2.8 & & 14 & & 14 \\
\hline Opaques & & 5.5 & & 25 & & 30 \\
\hline Tachylyte & & 17.1 & & 93 & & 78 \\
\hline \multirow{2}{*}{$\begin{array}{l}\text { Opal (some is replacing } \\
\text { chlorophaeite). }\end{array}$} & & 3.5 & & 16 & & 19 \\
\hline & & 100.0 & & 500 & & 500 \\
\hline \multicolumn{7}{|c|}{ Plagioclase/pyroxene $=0.91$} \\
\hline \multicolumn{7}{|c|}{$100-($ glass + opaque $) /$ pyroxene $=2.08$} \\
\hline Solidification Index: $s$ & $=35$. & & & & & \\
\hline
\end{tabular}


SAMPLE A-1268 (Taken from 30 feet below the flow top) Description

The rock is full of small phenocrysts of plagioclase $(0.5$ to $0.8 \mathrm{~mm})$, and of clots of this plagioclase with microphenocrysts $(0.4 \mathrm{~mm})$ of pyroxene. The larger phenocrysts of plagioclase (greater than $1 \mathrm{~mm}$ ) that have cores of poikilitic pyroxene are rare, but as in A-1270, there are a few of them none however, are much larger than the microphenocrysts. They contain inclusions of bubbly-brown glass as well as pyroxene. The matrix of the rock is a black irresolvable tachylyte. olivine is in sparse microphenocrysts $(0.8 \mathrm{~mm})$. It is fresh, and difficult to tell from pyroxene. Microlite sizes are 0.05 to $0.3 \mathrm{~mm}$ for plagioclase; $0.05 \mathrm{~mm}$ grains for pyroxene, which however, is clotted into welded aggregates up to $0.5 \mathrm{~mm}$ long. One pyroxene phenocryst has inclusions of glass and olivine. There is a peculiar interstitial yellow-green mineraloid. Apparently it is opal, some of which has relic features (shrinkage cracks, inclusions) that indicate that it replaced chlorophaeite.

POINT COUNT $(1000$ POINTS $)$

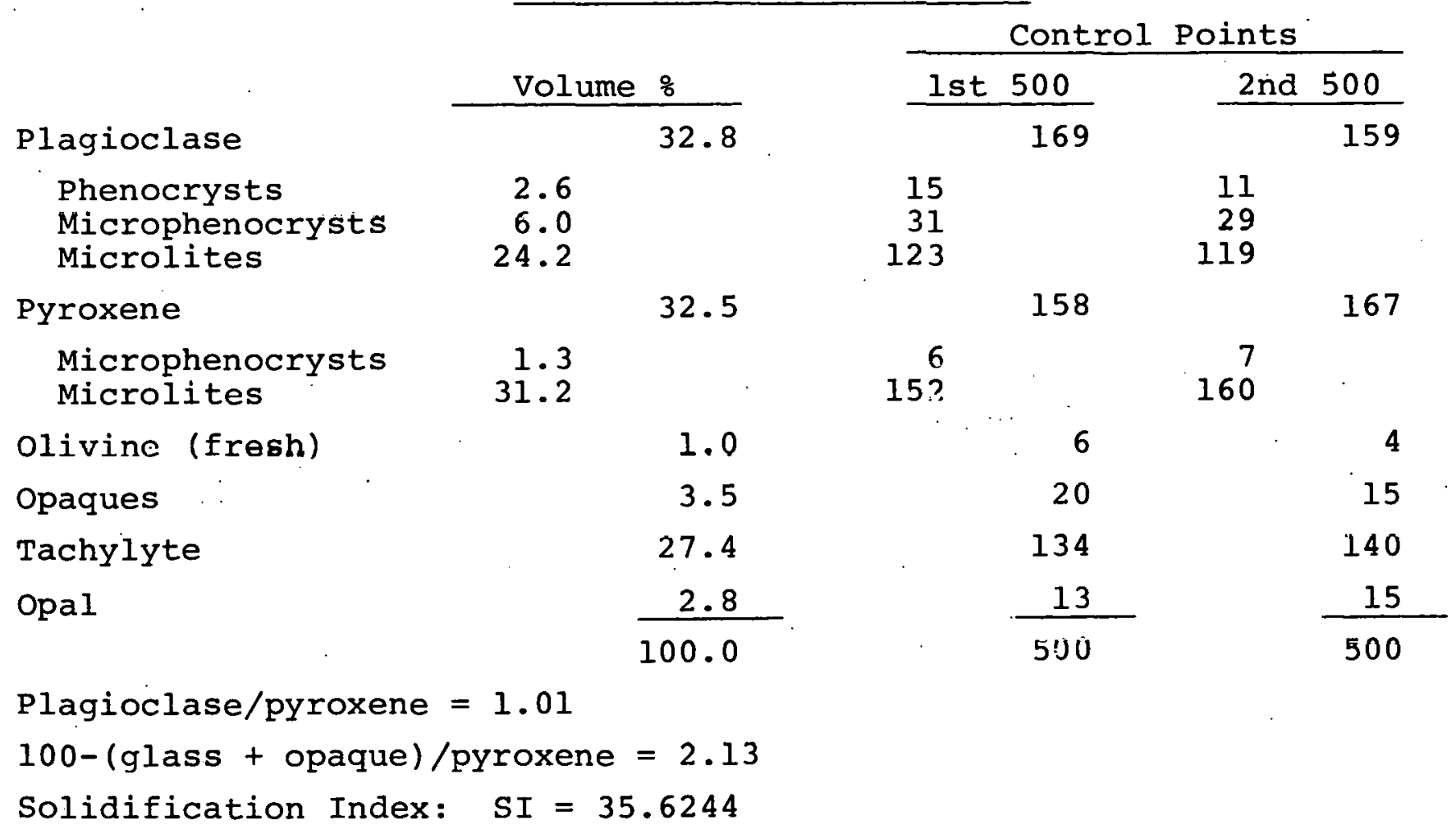


SAMPLE A-126.7 (Taken from 60 feet below the flow top) Description

This thin section is very similar to $A-1270$ and $A-1268$, the same description applies. It may be somewhat more crystalline at least the tachylyte has slightly less fuzzy boundaries, although it is still filled with black irresolvable dust and in places with larger skeletal magnetites. A striking example of a feldspar phenocryst with inclusions of pyroxene and glass was observed. It shows good resorption features both in early zones, and in a big "peninsula" of groundmass from one edge. Another example contains a carlsbad and some pericline twins. An olivine phenocryst with picotite(?) inclusions was also noted.

POINT COUNT : (1000 POINTS)

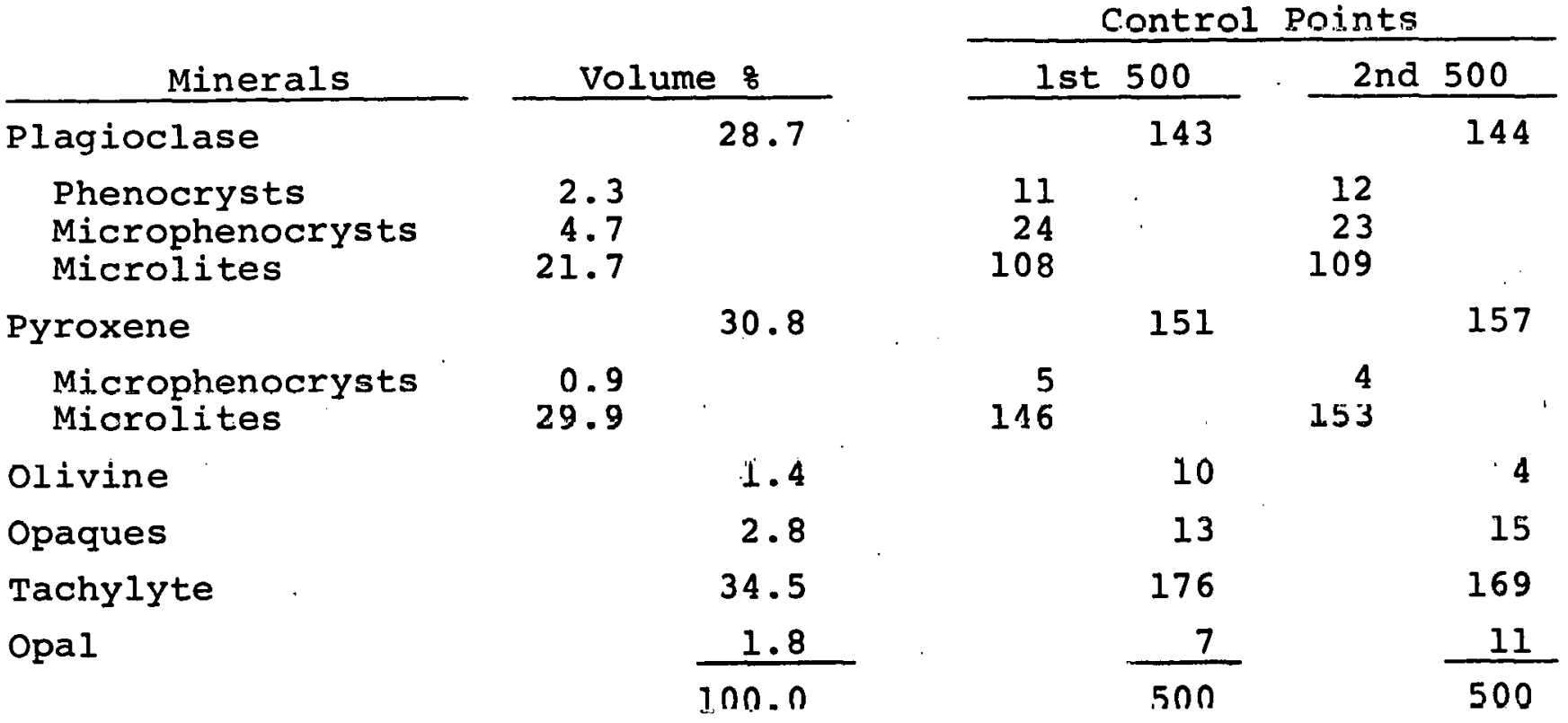

Plagioclase/pyroxene $=0.93$

100-(glass + opaque) $/$ pyroxene $=2.04$

Solidification Index: $S I=36.9604$ 
APPENDIX B

POMONA AND UMTANUM CHEMICAL COMPOSITION 
POMONA AND UMTANUM CHEMICAL COMPOSITION

Results of Pomona and Umtanum whole rock analyses using atomic absorption and trace element analyses using neutron activation for holes $\mathrm{DH}-2$, $\mathrm{DH}-4, \mathrm{DH}-5, \mathrm{DDH}-1, \mathrm{DDH}-3$, and $\mathrm{DC}-1$ are reported in Table $\mathrm{B}-1$. Table B-2 reports recent analyses of Pomona and Umtanum samples using $\mathrm{X}$-ray fluorescence. Location of all holes sampled is shown in Figure $\mathrm{B}-1$.

\section{TABLE B-1}

\section{POMONA AND UMTANUM CHEMICAL COMPOSITION} SERIAL IIPIII IIUIIIER IIII- 2 CORU.IIOLE

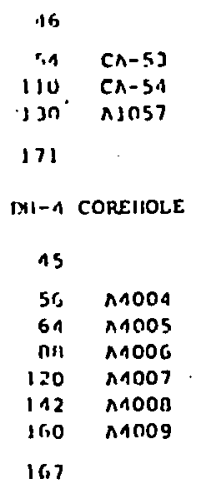

2300

2320

2332
2350

$217 n$ n $A 1203$

ini $\mathrm{in}$

2.11 Na10s

2435

DII-S COREIIOLE

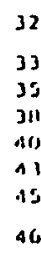

\section{$\wedge 5006$} A 5007 r.5non

Asoir Asolis

460

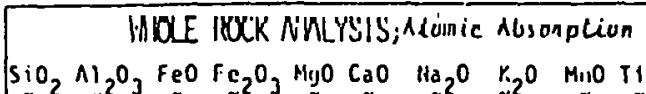

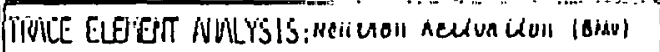

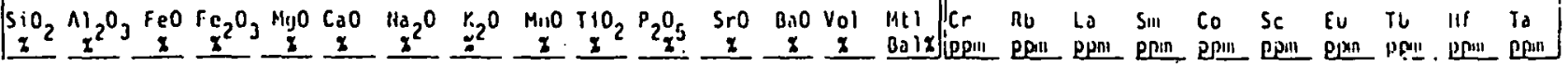
IOIDIU BNSALT MEHER

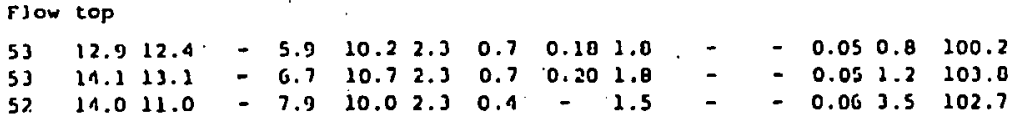

Flow bottom

POIOIM BASALT MEHLER

Flow top

So $\quad 13.610 .9 \quad-\quad 7.1 \quad 10.2 \quad 2.2 \quad 0.1 \quad 0.171 .6$

$51 \quad 13.611 .4 \quad-7.6 \quad 10.42 .2 \quad 0.2 \quad 0.17 \quad 1.6$

$51 \quad 13.610 .0=7.510 .22 .3 \quad 0.2 \quad 0.171 .6$

$52 \quad 13.510 .9=7.3 \quad 10.122 .3 \quad 0.2 \quad 0.10 \quad 1.6$

51 $13.510 .9 \quad-7.6 \quad 10.22 .30 .30 .191 .6$

S1 $13.310 .8 \quad-7.1 \quad 10.22 .4 \quad 0.3 \quad 0.271 .7$

$0.030 .07 \quad 3.0 \quad 99.0$

$\begin{array}{llll}- & 0.02 & 0.052 .3 \quad 100.813830\end{array}$

$\begin{array}{llllll}0.02 & 0.06 & 1.9 & 99.4 \quad 07 & 35\end{array}$

$-0.030 .052 .7 \quad 99.910035$

Flow lottom.

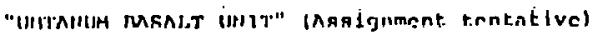

Flow toly (7)

so 13.212 .4

$52 \quad 13.411 .5$

$53 \quad 12.8 \quad 12.4$

$54 \quad 13.012 .3$

5513.013 .3

$-4.6$

$\begin{array}{llllll}7.1 & 2.7 & 1.2 & 0.25 & 2 .\end{array}$

$\begin{array}{llllll}4.1 & 7.1 & 3.1 & 1.2 & 0.24 & 2.1\end{array}$

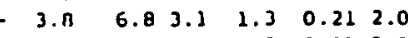

$\begin{array}{lllll}6.9 & 3.2 & 1.3 & 0.21 & 2.0\end{array}$

$-0.030 .061 .5$

99.111241

$\begin{array}{rrr}99.1 & 112 & 41 \\ 98.9 & 92 & 42\end{array}$

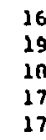

$\begin{array}{lll}4.3 & 43 & 35 \\ 5.3 & 46 & 33 \\ 1.9 & 13 & 34 \\ 1.9 & 11 & 3\end{array}$

1.9 A1

$4.8 \quad 42$

$\begin{array}{llllll}- & 3.5 & 7.03 .2 & 1.4 & 0.202 .1\end{array}$

Flow bottom (?)

$\begin{array}{lllll}7.2 & 3.3 & 1.4 & 0.20 & 2.1\end{array}$

- 0.030 .084 .790 .4

- 0.040 .105 .9100 .7

- 0.030 .092 .297 .71350

$\begin{array}{rrrr}0.030 .102 .2 & 98.92253\end{array}$

- 0.040 .101 .9100 .71184

$-0.010 .101 .7101 .0$

POMOIHA HASNLT MEMBER

Flow toll

$53 \quad 14.0 \quad 10.8$

53.23 .010 .8

2.ग. 10.0

$\begin{array}{lllllllll}52 & 14.211 .0 & - & 7.6 & 0.6 & 2.4 & 0.7 & 0.111 & 1.6 \\ 52 & 14.211 .4 & - & 7.7 & 9.6 & 2.1 & 0.7 & 0.11 & 1.6\end{array}$

-7.1
-7.1

$\begin{array}{lllll}9.7 & 2.1 & 0.3 & 0.16 & 1.6\end{array}$

$-0.020 .053 .103103 .6$

if $14.211 .0-7 . n \quad 0.52 .40 .50 .121 .6$

$51 \quad 13.010 .6-7.4 \quad 9.12 .10 .60 .171 .6$

- 0.020 .054 .5103 .2

- U.ن3 0.05 2.4100 .8

- $0.030 .052 .3102 .21063217 \quad 1.011321 .1-3.1$ -

rlow bottom

"ÜrRnNUM BASALT UHIT" (AggignmenE tenEaELVO)

Flow top

$\begin{array}{lll}52 & 12.7 & 22.7\end{array}$

$53 \quad 12,912.9$

S4 12.712 .4

5. $\quad 22.922 .1$

$52 \quad 12.622 .7$

Sh 12.712 .7

35.12 .012 .11

$55 \quad 12.422 .9$

$55 \quad 12.6212 .5$

$=3.9$
$=3.9$
$=3.1$
$=3.1$
$=3.1$
$=3.9$
$=3.9$

$\begin{array}{lll}7.6 & 3.1 & 1.5 \\ 7.2 & 3.0 & 1.5 \\ 7.0 & 3.2 & 1.6 \\ 7.1 & 3.3 & 1.6 \\ 7.4 & 3.1 & 1.6 \\ 7.0 & 3.2 & 1.6 \\ 7.3 & 3.3 & 1.3 \\ 7.5 & 3.2 & 1.2\end{array}$

- 2.2

- 0.0 .10 .1152 .4101 .7

plow bottom

$-2,2$

$-2.2$

- 2.2

- 2.2

- 2,2

0.081 .6

- 0.061 .0

$-0.0 n 1.3$

$-0.092 .7101 .5117-25 \quad 7.339331 .7-7.5=$ 
Table B-I (continued)

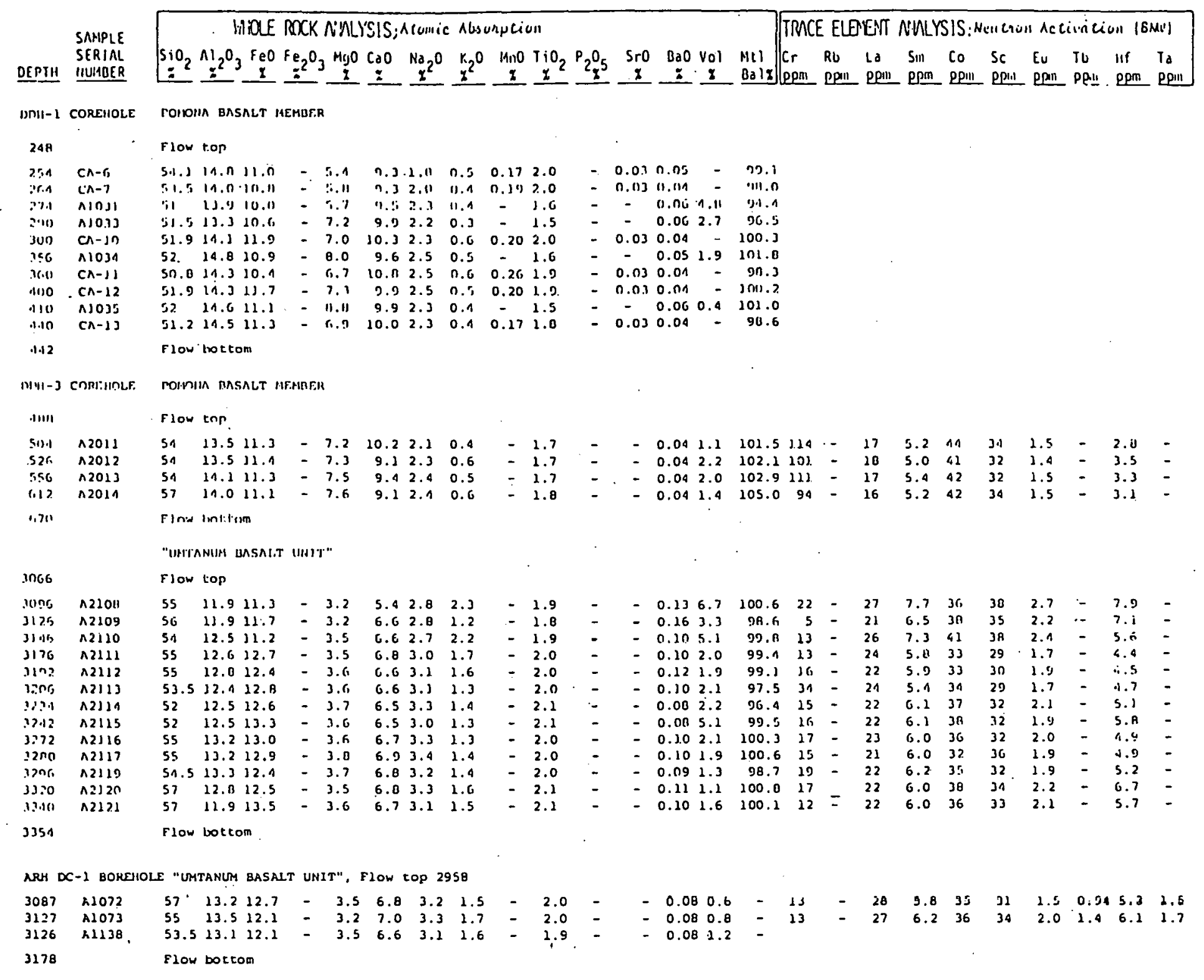


TABLE B-2

\section{POMONA AND UMTANUM X-RAY FLUORESCENCE}

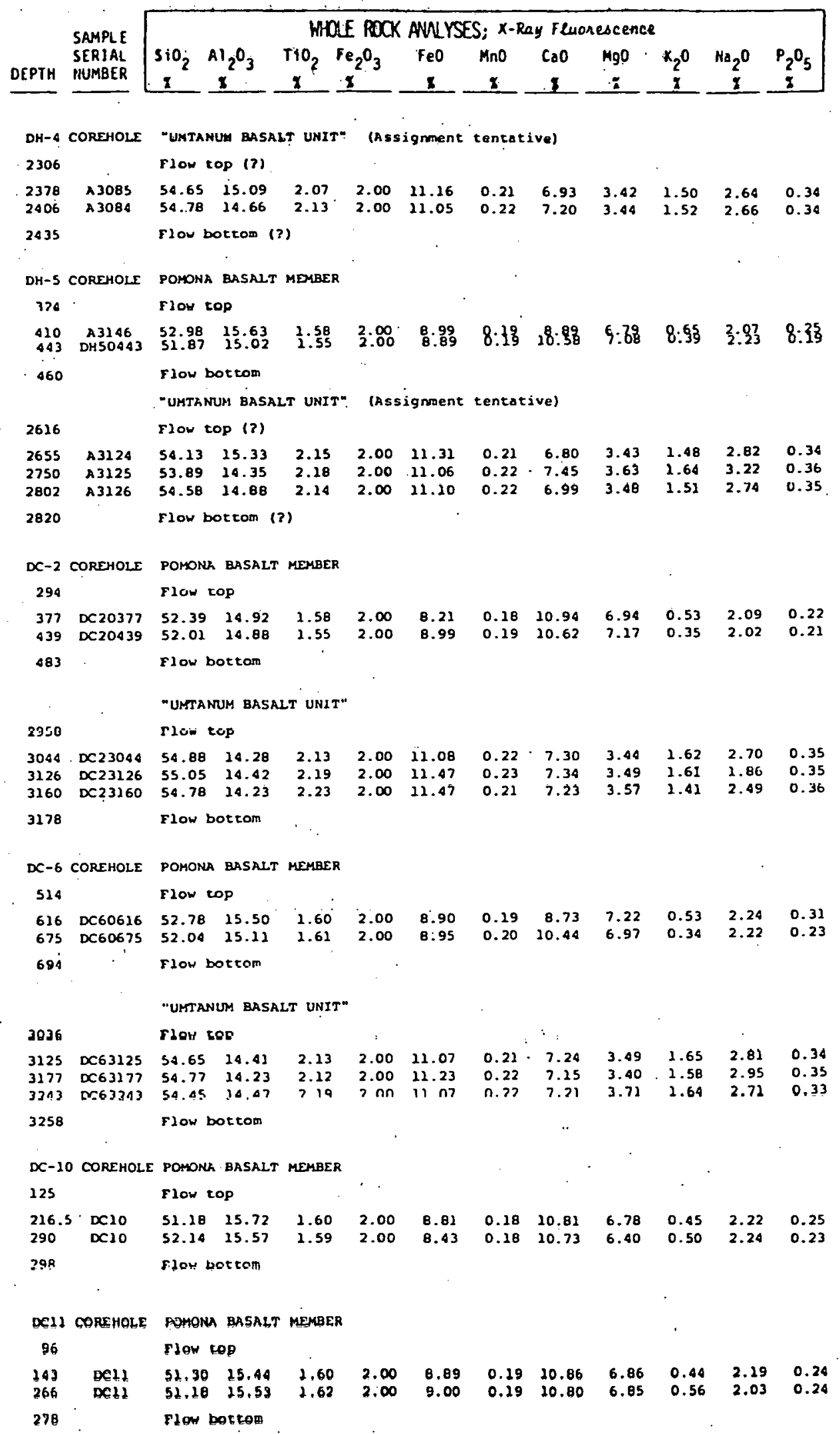




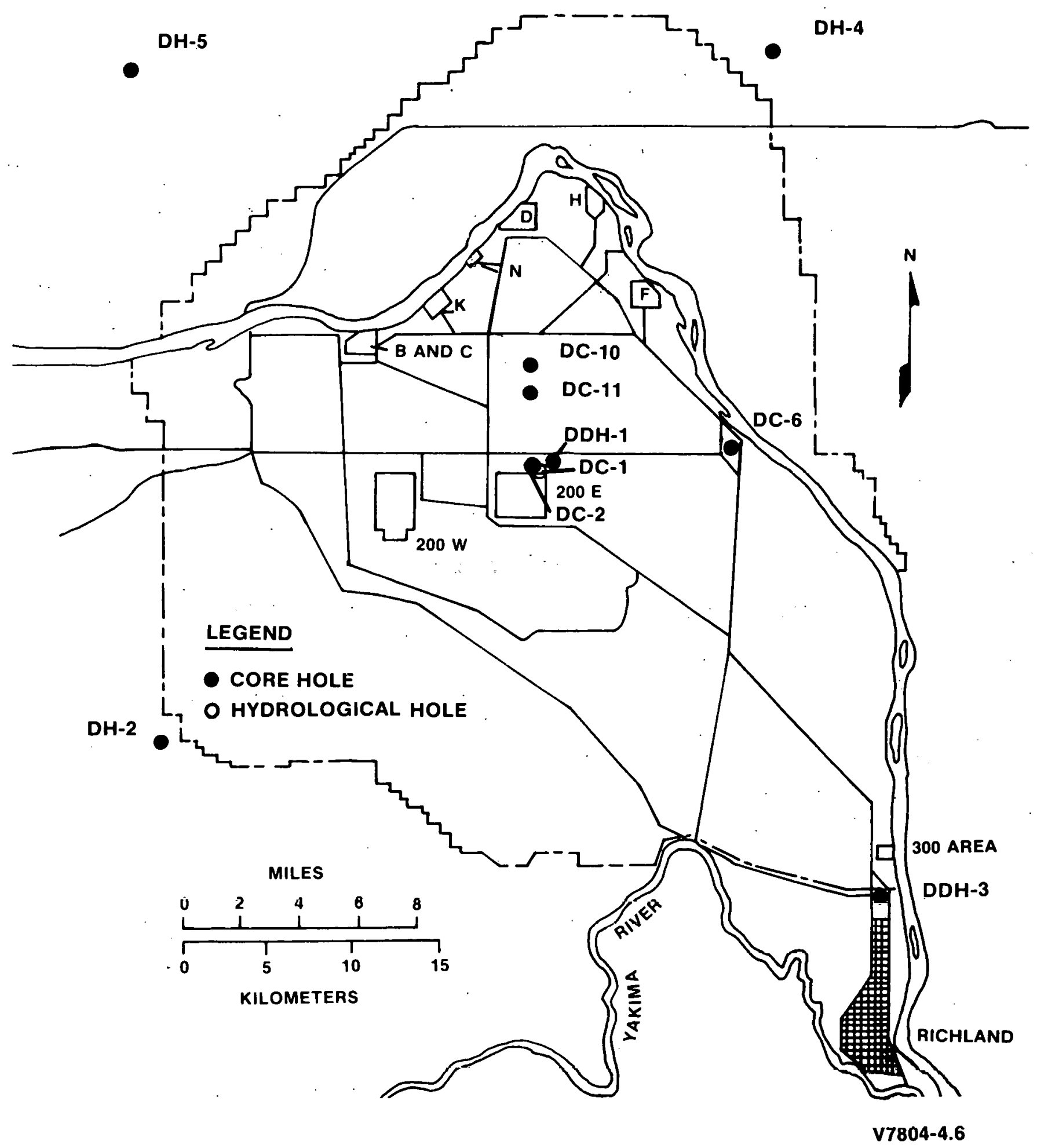

FIGURE B-I

HANFORD AREA MAP SHOWING LOCATION OF WELLS SAMPLED 


\section{APPENDIX C}

PETROGRAPHIC DESCRIPTION OF THE UMTANUM FLOW 
PETROGRAPHIC DESCRIPTION OF THE UMTANUM FLOW

Well DDH-3

Top of Umtanum Flow at 3,125 feet

Base of Umtanum Flow at 3,325 feet

SAMPLE A-2117 (Taken from a depth of 3,280 feet) Description

An extremely fine grained, glassy rock consisting of tachylyte pools crowded against a feeble network of thin $10.1 \mathrm{~mm}$ long and $0.025 \mathrm{~mm}$ thick) plagioclase microlites and shapeless grains of pyroxene $(0.3$ to $0.4 \mathrm{~mm}$ in diameter). Scattered small vesicles are partly filled with altered chlorophaeite and opal.

POINT COUNT ( 1000 POINTS)

Control Points

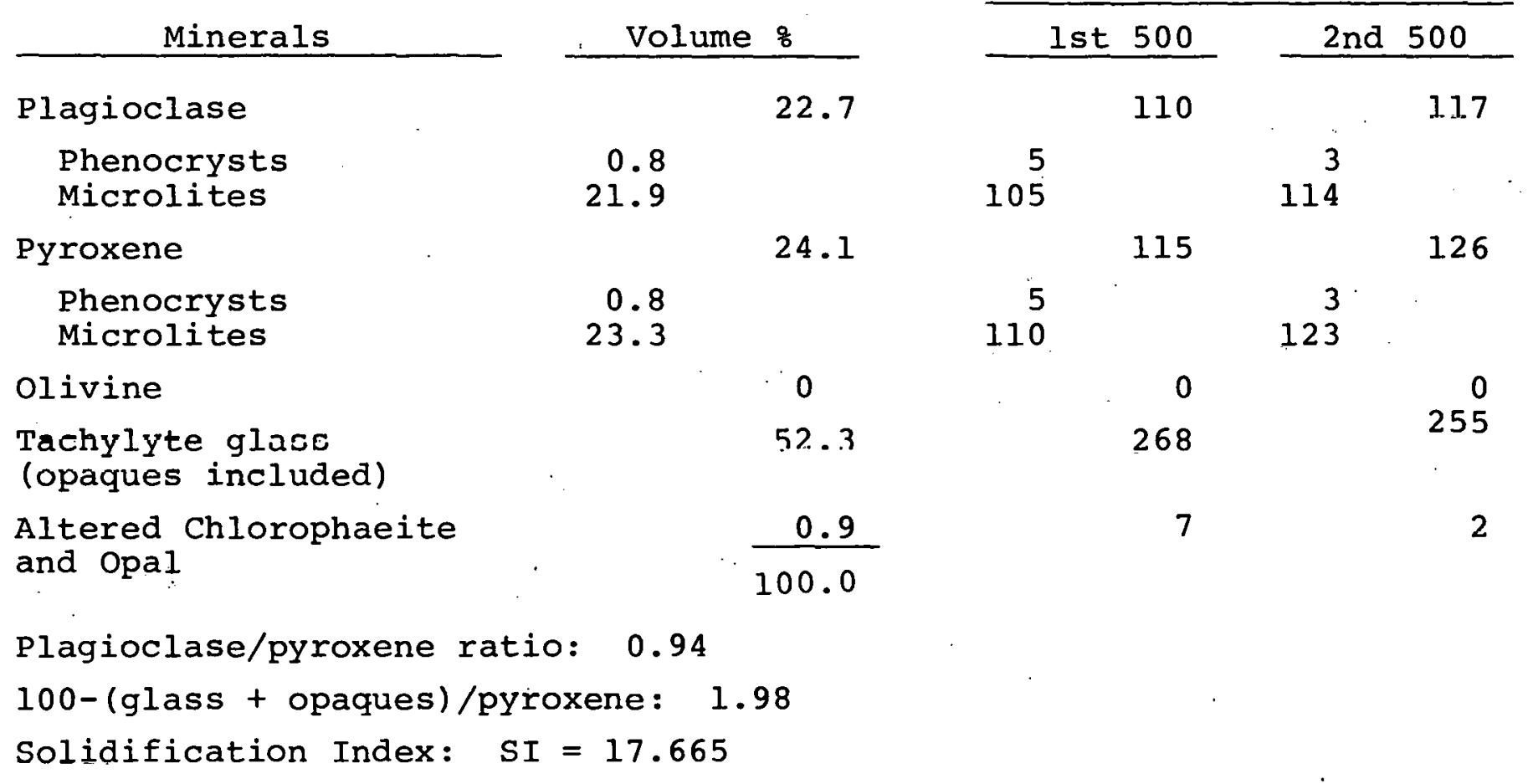


SAMPLE A-2120 (Taken from a depth of 3,320 feet) Description

Section is thick. Shows the usual microphenocrysts of plagioclase $(0.7 \mathrm{~mm}$ long). Rounded grains, tabular clotted plates, and rare microphenocrysts of green pyroxene, large euhedral opaques, and a deep brown glass - nearly clear except for a spattering of tiny spherical opaques. Only a little chlorophaeite.

\section{POINT COUNT (1000 POINTS)}

Control Points

\begin{tabular}{|c|c|c|c|c|}
\hline Minerals & Volume \& & lst 500 & 2nd & 500 \\
\hline Plagioclase & 38.6 & 190 & & 196 \\
\hline $\begin{array}{l}\text { Microphenocrysts } \\
\text { Microlites }\end{array}$ & $\begin{array}{r}1.1 \\
37.5\end{array}$ & $\begin{array}{r}5 \\
185\end{array}$ & $\begin{array}{r}6 \\
190\end{array}$ & \\
\hline Pyroxene & 38.9 & 196 & & 193 \\
\hline olivine (saponitized) & 0.2 & 1 & & 1 \\
\hline Opaques & 7.6 & 38 & & 38 \\
\hline Glass + crystallites & 14.4 & 73 & & 71 \\
\hline Chlorophaeite & 0.0 & $\therefore 0$ & & 0 \\
\hline Apatite & 0.3 & 2 & & 1 \\
\hline . & $\therefore 100.0$ & 500 & & 500 \\
\hline Plagioclase/pyroxene = & 0.99 & & & \\
\hline $100-($ glass + opaque $) / 1$ & roxene $=2.26$ & & & \\
\hline Solidification Index: & $S I=16.746$ & & & \\
\hline
\end{tabular}




\section{Well DH-5}

Top of Umtanum Flow at 2,615 feet

Base of Umtanum Flow at 2,825 feet

SAMPLE A-5101 (Taken from a depth of 2,650 feet)

\section{Description}

Although this rock appears aphanitic to: glassy, point counting indicates not more than 20-30 percent glass, but the microiltes which compose most of its bulk are so tiny (mostly less than $0.25 \mathrm{~mm}$ ) that they "swim" in glass of the thickness of a thin section. Because the dark brown glass is transparent, the amount of glass is constantly understated by the method. of point counting; as microlites can be seen through it. Microphenocrysts are almost nil. Only 6 of plagioclase and 1 of pyroxene were encountered in counting 1000 points. Apatite is much more abundant than normal, but because it is in such tiny crystals, it was rarely counted. The small amount of mineraloid in the rock has been. largely replaced by opal and chalcedony.

\section{POINT COUNT $(1000$ POINTS $)$}

Control Points

\begin{tabular}{|c|c|c|c|}
\hline Minerals & Volume $\%$ & lst 500 & 2nd 500 \\
\hline Plagioclase & 46.4 & 236 & 228 \\
\hline Pyroxene & 26.2 & 135 & 127 \\
\hline Opaques & 5.1 & 18 & 33 \\
\hline Glàss & 19.0 & 97 & 93 \\
\hline Chlorophaeite & 2.9 & 12 & 17 \\
\hline Apatite & 0.1 & 0 & 1 \\
\hline \multirow{2}{*}{$\begin{array}{l}\text { Opal and Chalcedony } \\
\text { (after chlorophaeite) }\end{array}$} & 0.3 & 2 & 1 \\
\hline & 100.0 & 500 & 500 \\
\hline
\end{tabular}


SAMPLE A-5103 (Taken from a depth of 2,692 feet)

\section{Description}

This second thin section, taken $42^{\prime}$ deeper in the 210-foot flow (or flow units) than $A-5101$ is richer in glass, but nevertheless, will make a more accurate point count. The tachylyte has cleared by nucleating small beads of opaque, which can be clearly discriminated from the translucent brown glass. Also this rock shows clearly what could only be anticipated from the ones above - the "poker-chip" structure is formed by the stretching and smearing out of tiny vesicles and diktytaxitic patches, and infilling of the cavities by chlorophaeite, some of which has altered to clay, opal; and chalcedony.

The rock is essentially without microphenocrysts; only three were encountered in 1000 points counted. All were plagioclase less than $0.7 \mathrm{~mm}$ long. Microlites range from 0.07 to $0.10 \mathrm{~mm}$.

\section{POINT COUNT (1000 POINTS)}

\begin{tabular}{|c|c|c|c|}
\hline & \multirow[b]{2}{*}{ Volume $\&$} & \multicolumn{2}{|c|}{ Control Points } \\
\hline Minerals & & lst 500 & 2nd 500 \\
\hline Plagioclase & 32.1 & 162 & 159 \\
\hline Pyroxene & 19.4 & 90 & 104 \\
\hline Opaques & 4.1 & 15 & 26 \\
\hline Glass & 40.7 & 216 & 191 \\
\hline Chlorophaeite & 3.2 & 14 & 18 \\
\hline \multirow{2}{*}{$\begin{array}{l}\text { Opal, Chalcedony, } \\
\text { zeolite }\end{array}$} & 0.5 & 3 & 2 \\
\hline & 100.0 & 500 & 500 \\
\hline Plagioclase/pyros & 1.64 & & \\
\hline 100-(glass + opag & pyroxe & & \\
\hline
\end{tabular}


SAMPLE A-5.106 (Taken from a depth of 2,752 feet)

\section{Description}

Unlike the preceding thin sections, this one shows a few microphenocrysts $(0.6 \mathrm{~mm})$ and a single small plagioclase phenocryst $(1.5 \mathrm{~mm})$. Plagioclase and pyroxene microlites are very small $(0.1$ to $0.05 \mathrm{~mm})$. The glass is deep brown and relatively clear. Opaques have nucleated into clearly defined euhedral grains. Only a trace of mineraloid (chlorophaeite) is present, and ciays or other alteration products are virtually nil. Because this is the best thin section, and because of the importance of this flow as a marker, two sets of 1000 points were counted by two separate operators with these results:

Combined 8

Plagioclase

Microphenocrysts

Microlites

Pyroxene

Microphenocrysts

Microlites

Opaques

Glass

Apatite

Chlorophaeite
36.35

Operator 1

171

$\begin{array}{rr}6 & 13 \\ 165 & 167\end{array}$

180 13
167
25.50

127

119

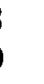

5.50

32.10

0.10

$\frac{0.45}{100.00}$

\begin{tabular}{rrr}
37 & & 30 \\
164 & & 161 \\
0 & & 1 \\
1 & & $\frac{1}{1}$ \\
\hline 500 & & 0
\end{tabular}

128

2
126

Operator 2

\begin{tabular}{rrrr}
\multicolumn{3}{c}{ Operator 2} \\
\hline & 185 & & 191 \\
3 & & 6 & \\
182 & & 185 & \\
& 131 & & 124 \\
2 & & 0 & \\
129 & $\cdot$ & 124 & \\
& 21 & & 22 \\
157 & & 160 \\
1 & & 0 \\
5 & & 3 \\
\hline 500 & & 500
\end{tabular}

The 2000 points combined give the mode (volume $\%$ ) listed in the first column, and the mineral ratios indicated below.

Plagioclase/pyroxene $=1.43$

$100-($ glass + opaques $) /$ pyroxene $=2.45$ 
SAMPLE A-510.9B (Taken from a depth of 2,812 feet)

\section{Description}

Two thin sections were cut at different angles with the platy structure. The larger one "B". was point counted.

The rock is exceedingly fine grained. Tiny $(0.2 \mathrm{~mm})$ plagioclase microlites are loosely grouped into bundles of 2 to 4 laths. Even smaller grains of pyroxene are more closely grouped into tiny clots or elongate clusters. Some clusters appear to be on the way toward making larger microlites (or microphenocrysts) by synneusis. Microphenocrysts of eilles plagioelage or pyrokone are virtually absent - less than a dozen in the entire thin sèction. The opaques are euhedral microlites; as a reoult, the glass is relatively clear. Chalcedony rims one vesicle, and slightly altered chlorophaeite has been smeared along the platy structure in places.

\section{POINT COUNT (1000 POINTS)}

\begin{tabular}{|c|c|c|c|}
\hline & \multirow[b]{2}{*}{ Volume $\%$} & \multicolumn{2}{|c|}{ Control Points } \\
\hline & & lst 500 & 2nd 500 \\
\hline Plagioclase & 44.1 & 216 & 225 \\
\hline Pyroxene & 34.3 & 167 & 176 \\
\hline Opaques & 5.4 & 30 & 24 \\
\hline Glass & 15.8 & 85 & 73 \\
\hline Apatite & 0.2 & 0 & 2 \\
\hline \multirow[t]{2}{*}{ Chlorophaeite } & 0.2 & 2 & 0 \\
\hline & 100.0 & 500 & 500 \\
\hline
\end{tabular}


APPENDIX D

BCR-1 DATA 
TABLE $D-1$

BCR-1 DATA FROM ARHCO AND ROCKWFLL ANALYSIS

\begin{tabular}{|c|c|c|c|c|c|c|c|c|c|c|c|c|}
\hline \multirow[b]{2}{*}{ DEPTH } & \multirow{2}{*}{$\begin{array}{l}\text { SAMPLE } \\
\text { SERIAL } \\
\text { MUMBER }\end{array}$} & \multicolumn{11}{|c|}{ WHOLE ROCK' NWLYSES; $x$-Ray Fluonescence } \\
\hline & & $\mathrm{SiO}_{2}$ & $\mathrm{Al}_{2} \mathrm{O}_{3}$ & $\mathrm{TiO}_{2}$ & $\begin{array}{c}\mathrm{Fe}_{2} \mathrm{O}_{3} \\
x\end{array}$ & $\begin{array}{c}\text { Feo } \\
x\end{array}$ & $\begin{array}{c}\text { Nno } \\
x\end{array}$ & $\begin{array}{c}\mathrm{CaO} \\
x\end{array}$ & $\begin{array}{c}\mathrm{MgO} \\
\vdots\end{array}$ & $\mathrm{K}_{2} \mathrm{O}$ & $\mathrm{Ha}_{2} \mathrm{O}$ & $\mathrm{P}_{2} \mathrm{O}_{5}$ \\
\hline
\end{tabular}

BCR-1 BASALT STANDARD

ARHCO BASALT ANALYSES JULE-JULY 1977 (WSU Special Report)

\begin{tabular}{|c|c|c|c|c|c|c|c|c|c|c|c|}
\hline$\kappa 5218$ & 54.14 & 14.71 & 2.22 & 2.00 & 10.74 & 0.21 & 7.00 & 3.70 & 1.89 & 3.07 & 0.32 \\
\hline$\times 5219$ & 54.38 & 14.70 & 2.16 & 2.00 & 10.93 & 0.20 & .7 .12 & 3.53 & 1.87 & 2.78 & 0.33 \\
\hline K5 220 & 54.55 & 14.62 & 2.22 & 2.00 & 10.67 & .20 & 6.91 & 3.66 & 1.94 & 2.90 & 0.33 \\
\hline 5221 & 54.39 & 5.03 & .29 & .00 & 10.25 & .21 & 7.34 & 3.66 & 1.89 & .71 & 0.33 \\
\hline 5222 & 54.22 & 4.74 & 23 & .00 & 10.76 & .21 & 6.91 & 3.65 & 1.92 & 3.03 & .33 \\
\hline 5223 & 54.28 & $25.0 \varepsilon$ & .17 & .00 & 20.72 & .21 & 7.14 & 3.54 & 1.84 & 2.69 & .33 \\
\hline 5224 & 54.44 & 14.70 & .23 & .00 & 10.73 & .21 & C.92 & 3.51 & 1.88 & 3.05 & 0.33 \\
\hline 5225 & 54.30 & 14.60 & .27 & .00 & 10.60 & .21 & 7.15 & .55 & 1.86 & .03 & 32 \\
\hline 5235 & 54.54 & 5.16 & .21 & .00 & 10.89 & .20 & 7.17 & 3.74 & 1.74 & 2.01 & 0.33 \\
\hline 5236 & 54.87 & 15.04 & .21 & חח ת. & 20.72 & .20 & 7.25 & .78 & 1.78 & 1.82 & 0.33 \\
\hline 5237 & 54.59 & 14.98 & .23 & 2.00 & 11.05 & c. 21 & 7.22 & 3.68 & 1.77 & 1.95 & 0.33 \\
\hline $\begin{array}{l}K 5238 \\
\text { ISE } 239\end{array}$ & & & $\begin{array}{l}2.24 \\
2.20\end{array}$ & & & $\begin{array}{l}0.21 \\
0.20\end{array}$ & $\begin{array}{l}7.27 \\
7.14\end{array}$ & $\begin{array}{l}3.61 \\
3.77\end{array}$ & $\begin{array}{l}1.84 \\
1.73\end{array}$ & $\begin{array}{l}1.96 \\
\text { R.01 }\end{array}$ & $\begin{array}{l}0.34 \\
0.32\end{array}$ \\
\hline$\times 5240$ & & 24.55 & 2.26 & 2.00 & 10.95 & 0.21 & 7.30 & 3.57 & 1.86 & 2.12 & 0.34 \\
\hline K5241 & & & 2.21 & 2.00 & & 0.20 & 7.14 & 3.67 & 1.75 & 2.02 & 0.33 \\
\hline 5242 & & & 2.26 & 2.00 & & 0.21 & 7.31 & 3.56 & 1.86 & 2.26 & 0.34 \\
\hline 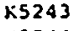 & & & 2 & & 10.82 & 0.21 & 7.22 & 3.66 & 1.76 & 1.95 & 0.33 \\
\hline 5244 & 54.93 & 15.02 & 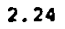 & 0 & 10.51 & 0.21 & 7.21 & 3.67 & 1.80 & 2.08 & 0.33 \\
\hline 5245 & 54.89 & & 24 & Do & 10.62 & 0.21 & 7.35 & 3.62 & 1.82 & 2.21 & 0.34 \\
\hline 5240 & 55.01 & 14.98 & 2.23 & 2.00 & 10.58 & 0.21 & 7.27 & 3.63 & 1.81. & 1.95 & $0,3,3$ \\
\hline
\end{tabular}

\begin{tabular}{|c|c|c|c|c|c|c|c|c|c|c|c|c|}
\hline \multirow[b]{2}{*}{ DEPTH } & \multirow{2}{*}{$\begin{array}{l}\text { SAMPLE } \\
\text { SER IAL } \\
\text { NU!ABER }\end{array}$} & \multicolumn{11}{|c|}{ 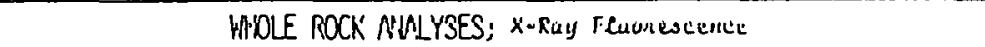 } \\
\hline & & $\mathrm{SiO}_{2}$ & ${ }_{2}^{A}{ }_{2} \mathrm{O}_{3}$ & $\underset{x}{\mathrm{TiO}_{2}}$ & $\mathrm{Fe}_{2} \mathrm{O}_{3}$ & $\begin{array}{c}\mathrm{feO} \\
x\end{array}$ & Mino & $\mathrm{CaO}$ & $\begin{array}{c}\mathrm{MgO} \\
:\end{array}$ & $\mathrm{K}_{2} \mathrm{O}$ & ${ }_{7}^{\mathrm{Na}}{ }_{2} \mathrm{O}$ & $\mathrm{P}_{2} \mathrm{O}_{5}$ \\
\hline
\end{tabular}

BCR-1 BASALT STANDARD

WSU Report ROCKWELL 1, 14 March 2978

$\begin{array}{llllllllllll}\text { BCRP900 } & 55.24 & 14.56 & 2.25 & 2.00 & 10.54 & 0.19 & 6.95 & 3.70 & 1.74 & 2.49 & 0.33\end{array}$

WSU Report ROCKIVELI 2, 22 April 1978

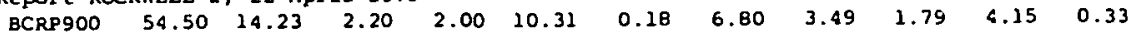

WSU Report ROCKWELL 3, 24 March 1978.

$\begin{array}{llllllllllll}\text { BCRP900 } & 53.93 & 14.26 & 2.24 & 2.00 & 10.49 & 0.19 & 6.97 & 3.61 & 1.85 & 4.11 & 0.34\end{array}$

WSU Raghrt. ROCKWELL 4, 21 April 1978

$\begin{array}{llllllllllll}\text { BCRP900 } & 55.34 & 14.50 & 2.26 & 2.00 & 10.55 & 0.19 & 6.9 \% & 3.51 & 1.85 & 2.49 & 0.34\end{array}$

WSU RepOrt ROCKTELL 5.13 April 1978

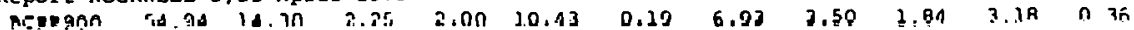

WSU Report ROCKWELL 6, 19 April 1978

$\begin{array}{llllllllllll}\text { DCRF } 900 & 54.97 & 14.60 & 2.26 & 2.00 & 10.49 & 0.19 & 6.93 & 3.47 & 1.84 & 2.88 & 0.38\end{array}$

WSU RePOTE ROCKWELL 7, 22 April 1978

$\begin{array}{llllllllllll}B C R P 900 & 55.18 & 14.55 & 2.25 & 2.00 & 10.59 & 0.19 & 6.88 & 3.41 & 1.80 & 2.80 & 0.34\end{array}$

WSU RePUIt ROCKWELL $\theta, 2$ MAY 1970

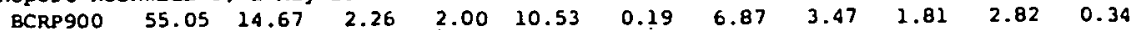

WSU Report ROCKWELL 9, A MaY 1978

$\begin{array}{llllllllllll}\text { BCRP900 } & 55.49 & 14.33 & 2.26 & 2.00 & 10.63 & 0.19 & \epsilon .92 & 3.41 & 1.81 & 2.63 & 0.35\end{array}$

WSU Report ROCKWELL 10, 12 May 1978

$\begin{array}{llllllllllll}\text { BCRP900 } & 55.38 & 14.33 & 2.24 & 2.00 & 10.50 & 0.19 & 6.87 & 3.48 & 1.80 & 2.85 & 0.36\end{array}$

WEU ROPOKE ROCK.WELI 11

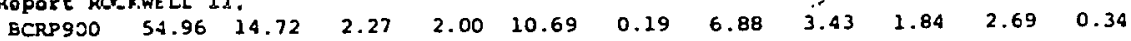

HSO Keport RUCKREL 12, 2 Jül 2970

$\begin{array}{llllllllllll}\text { BCRP900 } & 54.56 & 14.63 & 2.28 & 2.00 & 10.63 & 0.19 & 6.94 & 3.51 & 1.83 & 3.06 & 0.35\end{array}$

WSU Report ROCKWELL 13,19 June 1978 $\begin{array}{llllllllllll}\text { BCRP900 } & 55.11 & 14.47 & 2.26 & 2.00 & 10.61 & 0.19 & 6.86 & 3.51 & 1.82 & 2.84 & 0.34\end{array}$

WSU KEDOTE ROCNWELL 14, 19 JunE 1978 $\begin{array}{llllllllllll}\text { BCRP900 } & 55.15 & 14.37 & 2.26 & 2.00 & 10.63 & 0.19 & 6.87 & 3.50 & 1.83 & 2.86 & 0.35\end{array}$

WSU RePOTt RCERWLLI 15, 23 Jume 1970

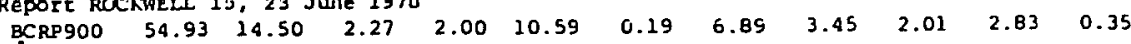

WSU REPOrt ROCKWEIL 16,7 July 1978 $\begin{array}{llllllllllll}\text { BCRP900 } & 54.91 & 14.53 & 2.26 & 2.00 & 10.54 & 0.19 & 6.89 & 3.53 & 1.82 & 2.97 & 0.36\end{array}$

WSU REPOYT ROCKWELL 17,

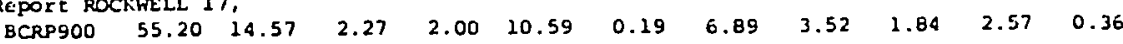

WSU RePOIT ROCKWELL 18, 24 JUIY 1978 $\begin{array}{llllllllllll}\text { BCFP900 } & 55.05 & 14.59 & 2.26 & 2.00 & 10.50 & 0.19 & 6.84 & 3.50 & 1.84 & 2.88 & 0.36\end{array}$

WSU Report ROCKWELL 19, 3 August 1978 $\begin{array}{llllllllllll}\text { BCRP900 } 55.06 & \times 4.62 & 2.27 & 2.00 & 10.64 & 0.19 & 6.93 & 3.48 & 1.86 & 2.60 & 0.36\end{array}$

WSU REPOTE ROCKWELL 20. $\begin{array}{llllllllllll}\text { BCRP9O0 } & 55.10 & 14.03 & 2.24 & 2.00 & 10.60 & 0.19 & 6.87 & 3.45 & 1.82 & 2.79 & 0.34\end{array}$ 
TABLE D-2

1972 VALUES FOR INTERNATIONAL GEOCHEMICAL STANDARDS FOR BASALT (After Flanagan, 15

data for recommended, averages, or magnitudes)

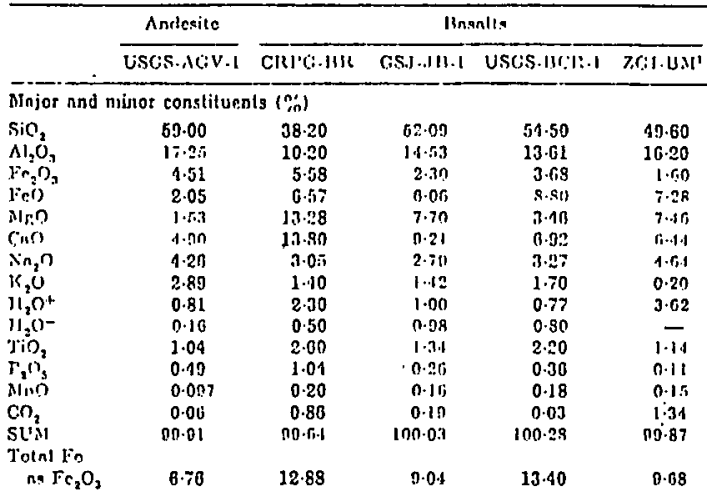

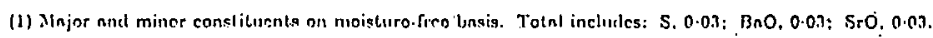

Trnco elements (ppns, or units slinurn)

\begin{tabular}{|c|c|c|c|c|c|}
\hline$\Lambda_{E}(\mu p m)$ & 0.11 & - & - & $0.0 .3 \pi$ & 0.06 \\
\hline$A=\{p \mid m\}$ & 0.8 & - & - & 0.70 & 14 \\
\hline$\left.A \cup\left(p \Gamma^{1}\right)\right\}$ & 0.6 & - & - & 0.95 & 5 \\
\hline 13 (1יקו1י) & 3 & - & 10 & 3 & 9 \\
\hline $\operatorname{Bn}\left(p_{1}, n\right)$ & 1208 & 1050 & 100 & 675 & 203 \\
\hline$\left.B_{0}(p) \times m\right)$ & 3 & 1 & - & 1.7 & $1 \cdot 3$ \\
\hline Di $(1, m)$ & 0.057 & - & - & 0.050 & 0.3 \\
\hline $13 r(p p m)$ & 0.5 & - & 0.6 & 0.15 & - \\
\hline $\mathrm{C}$ (1pin) & - & -. & - & 330 & - \\
\hline $\mathrm{Crl}(\mathrm{r} ! \mathrm{m})$ & 0.09 & - & 0.1 & 0.12 & - \\
\hline Cn $(\mathrm{rnm})$ & .03 & - & 07 & 53.8 & 23 \\
\hline CI & 110 & - & 190 & .50 & $19 n$ \\
\hline $\operatorname{Cos}(1,1)$ & 14.1 & 50 & 30 & 38 & 34 \\
\hline $\mathrm{Cr}\left(\mathrm{i}_{\mathrm{pm}}\right)$ & 12.2 & 420 & 417 & $17 \cdot 6$ & 123 \\
\hline Ce (pгm) & 1.6 & - & 1 & 0.05 & 1.7 \\
\hline$C_{11}(t \mid \times m)$ & 68.7 & 70 & 52 & 18.1 & 45 \\
\hline ny $(10 m)$ & 3.5 & - & $4 \cdot 1$ & 0.3 & 1 \\
\hline $\operatorname{Fir}(p) m)$ & 1.2 & - & 2.23 & 3.59 & 3 \\
\hline E⿰丿 (זpin) & 1.7 & - & $1 \cdot \sqrt{12}$ & 1.04 & 1.1 \\
\hline$F(p, m)$ & 435 & - & 360 & did & 250 \\
\hline Gn (purn) & 20.5 & 20 & 57 & $2 n$ & 15 \\
\hline Gd (spin) & 8.5 & - & $4 \cdot 80$ & $8 \cdot 0$ & 6 \\
\hline $\operatorname{lin}(n \cdot r)$ & J.J & - & - & 1.5 .1 & 1.5 \\
\hline H( $(1, j m)$ & 0.2 & - & 3.5 & 1.7 & 3.1 \\
\hline $\mathrm{Jlg}(\mathrm{pl}, \mathrm{b})$ & 15 & - & 14 & 10.7 & 20 \\
\hline 1lo $(\mathrm{ppm})$ & 0.5 & - & - & 1.2 & J.5 \\
\hline 1 (תויןוj) & - & - & - & $<1$ & - \\
\hline$J_{11}(1 p r m)$ & 0.04 & - & - & 0.095 & 0.03 \\
\hline Jr (pyly) & 0.011 & - & - & 0.001 & 6 \\
\hline $\operatorname{lon}(1,1)$ & 3.5 & 8.5 & 36 & 20 & B.n \\
\hline Ji (ppm) & 12 & 9 & 10.2 & 12.8 & 70 \\
\hline L.n (pprn) & 0.78 & - & 0.31 & 0.55 & 0.4 \\
\hline $\operatorname{Mn}(\mathrm{r} p \mathrm{~m})$ & 70.3 & -. & - & 1406 & $112 \pi$ \\
\hline $\operatorname{Mn}(p, j)$ & $2 \cdot 3$ & J & - & 1.1 & 0.17 \\
\hline$N$ (In) & 44 & - & - & 30 & $\overline{-}$ \\
\hline$N b(\mathrm{pnm})$ & 15 & - & - & 13.5 & 10 \\
\hline Sirl (prtn) & 30 & - & 25 & 29 & 16 \\
\hline $\operatorname{Ni}(p, m)$ & 18.5 & 270 & 1.30 & 15.8 & 67 \\
\hline $0(\%)$ & $47 \cdot 2.6$ & - & - & $4.5 \cdot 18$ & - \\
\hline$O a(p, b)$ & $<3.1$ & - & - & 0.1 & - \\
\hline ניm) & $35 \cdot 1$ & - & 14 & 17.6 & 12 \\
\hline 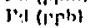 & $<\omega \cdot 5$ & - & - & 12 & - \\
\hline 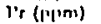 & 7 & - & - & 7 & J.5 \\
\hline rL $\left(p^{\prime}(b)\right.$ & 1 & - & - & 2 & $<i$ \\
\hline Rn (ppti) & 0.69 & - & 0.72 & $0.5 n$ & - \\
\hline dth $(p p m)$ & 67 & 4.1 & 11 & 46.0 & 12 \\
\hline (נוחיחין & $<6$ & - & - & 08 & 一 \\
\hline$\left.m h_{1}()_{1}, b\right)$ & - & - & - & 0.2 & - \\
\hline $1311(p \mid b)$ & - & - & - & 1 & - \\
\hline$s\left(y^{y}, m\right)$ & $\therefore 10$ & - & 50 & $J M 3$ & - \\
\hline Sb (ppm) & 4.5 & - & 0.2 & (.) & 2 \\
\hline Se (pp:m) & 13.4 & - & 26 & 3.J & 34 \\
\hline Sin $\left.(\Gamma)^{2}\right)$ & $<0.14$ & - & - & 0.10 & - \\
\hline (יויקין וניות & 5.0 & - & 4.8 & 6.6 & 4 \\
\hline Sn $\{m n+n\}$ & 1.2 & 8 & 2.3 & 2.6 & 1.7 \\
\hline $\mathrm{Sr}(\mathrm{ppm})$ & 657 & 1350 & $4 \overline{3} \dot{z}$ & $33 j$ & 233 \\
\hline$j_{n}(p \mathrm{pm})$ & 0.0 & - & 1 & 0.91 & 0.1 \\
\hline Th $\left(\mathrm{rl}^{\mathrm{m}}\right)$ & 0.70 & - & 0.5 & 1.0 & 1 \\
\hline $\operatorname{Tr}(\mid,(1) n)$ & $<1$ & - & - & $=1$ & - \\
\hline Th (יוי) & 0.41 & - & 0.4 & 0.0 & 3 \\
\hline$T i(1, u m)$ & B। 180 & - & - & 13760 & Q890 \\
\hline$T 1$ (ppm) & $I$ & - & - & 0.30 & 0.2 \\
\hline $\mathrm{Tm}(\mathrm{rrm})$ & 0.4 & - & - & 0.0 & - \\
\hline 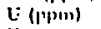 & 1.89 & - & 1.8 & 1.74 & 1 \\
\hline$v(p)$ & 12.5 & 210 & 300 & 309 & 180 \\
\hline W" & 0.55 & - & - & 0.10 & 1 \\
\hline$y(p, p)$ & $21 \cdot 3$ & $2 i$ & - & 37.1 & 20 \\
\hline$Y$ (ומקין) & 1.7 & $\&$ & 2.1 & $3 \cdot 30$ & .3 .5 \\
\hline Zn & 81 & 100 & 8.7 & 120 & 107 \\
\hline 7.r 'ppin) & 225 & 240 & .300 & 100 & 105 \\
\hline
\end{tabular}

